\title{
PORTRAYAL OF VIOLENCE AGAINST WOMEN IN GHANAIAN MOVIES
}

\section{Philip Acquaye}

Lecrurer/Head of Department, Mass Communication and Journalism, BluecCrest University College

Cite this article:

Philip Acquaye (2022),

Portrayal of Violence Against

Women in Ghanaian Movies.

British Journal of Mass

Communication and Media

Research 2(1), 14-53. DOI:

10.52589/BJMCMR-

KBE5RPGT

\section{Manuscript History}

Received: 17 Nov 2021

Accepted: 10 Dec 2021

Published: 18 Jan 2022

Copyright $\odot 2020$ The Author(s). This is an Open Access article distributed under the terms of Creative Commons AttributionNonCommercial-NoDerivatives 4.0 International (CC BY-NC-ND 4.0 ), which permits anyone to

share, use, reproduce and redistribute in any medium, provided the original author and source are credited.

\begin{abstract}
In media entertainment, violence is a commonplace. Media platforms tend to portray women in certain negative ways and as having more negative qualities than other members of society such as the male gender. These portrayals provide viewers with ways of thinking about and acting towards members of a particular group, thus affecting communication and perception. The study thus, seeks to investigate the portrayal of violence against women in Ghanaian movies in order to ascertain whether media portrayal of violence against women is merely a reflection of reality within our social structure or a distorted picture to reinforce violence against women. A purposive sampling technique was used in selecting the movies for the study. Three movies were selected and a content analysis of these movies were guided by three research questions aimed at investigating the forms of violence that are predominantly portrayed in Ghanaian movies, ascertain how these portrayals position women in the movies and analyse how these portrayals go to reinforce violence against women in Ghanaian movies. The findings of the study shows that portrayal of violence against women in Ghanaian movies is a reflection of realities in our social structure. These portrayals do not only reflect happenings in society but goes further to reinforce violence against women in Ghanaian communities.
\end{abstract}

KEYWORDS: Violence, Movies, Reinforcement, Reflection, Content Analysis 


\section{INTRODUCTION}

Violence, according to the World Health Organisation (WHO, 2002), is a universal phenomenon that permeates different communities in all countries; on the streets, in the homes, at schools, workplaces and institutions. The WHO again describes violence as a universal scourge that tears the fabric of communities and threatens the life, health and happiness of us all.

Violence occurs in different forms. Violence perpetrated against women is one of such. According to Watts and Zimmerman (2002), Violence against women is not only a manifestation of sex inequality, but also serves to maintain this unequal balance of power. In a cross sectional survey to investigate the global phenomenon of violence against women, it was revealed that perpetrators in most cases consciously use violence as a mechanism for subordination.

According to Khan (2000), violence against women is present in every country, cutting across boundaries of culture, class, education, income, ethnicity and age. The pervasive nature of violence against women and its far reaching effects has culminated in a global effort to tackle the issue head on.

In the year 2000, the United Nations through its member countries, pledged to combat all forms of violence against women as a step towards the realisation of the Millennium Development Goals by the year 2015 (Millennium Declaration, 2000). A Campaign to end all forms of violence against women was subsequently initiated in 2008 by the United Nations and spearheaded by its Secretary-General, Ban Ki-moon (UN, 2010).

The effort to end all forms of violence against women has over the years, included a criticism of how the media portray women (Larasi, 2012). Croteau and Hoynes (2003) explain that the media is a powerful agent of society and underscores the point that our understanding of our social world is largely facilitated and influenced by media texts. These media texts help to define our world and provide models for behaviours and attitudes.

A study by Bastian et al (2013) shares the concerns of Croteau and Hoynes and stresses that the media is an active agent of society that mirrors the day to day occurrences in our homes and communities. However, Larasi (2012) contends that with respect to portrayal of violence against women in the media, it is not merely an act in society that the media is mirroring rather media texts occasionally contain distorted realities thereby providing models for behaviours and attitudes as espoused by Croteau and Hoynes. The opinions of Larasi (ibid) and Bastian et al (ibid) on the role of media is quite divergent. The movies as a microcosm of media is pitched against these opinions: that the portrayal of violence against women is a reflection of realities in our social world; and that the media portrayal of acts of violence against women is merely a creation of the media to normalise acts of violence against women. In the light of these divergent opinions, this study seeks to investigate the portrayal of violence against women in movies in Ghana and further analyse the role of these movies in the portrayal of violence against women.

The United Nations Declaration on the Elimination of Violence against Women (1993) defines Violence against women as: 
Any act of gender-based violence that results in or is likely to result in physical, sexual or psychological harm or suffering to women, including threats of such acts, coercion, or arbitrary deprivation of liberty, whether occurring in the public or private life'.

Article 1 of the Declaration explains that violence against women shall be understood to encompass, but not be limited to, the following:

(a) Physical, sexual and psychological violence occurring in the family, including battering, sexual abuse of female children in the household, dowry-related violence, marital rape, female genital mutilation and other traditional practices harmful to women, non-spousal violence and violence related to exploitation;

(b) Physical, sexual and psychological violence occurring within the general community, including rape, sexual abuse, sexual harassment and intimidation at work, in educational institutions and elsewhere, trafficking in women and forced prostitution;

(c) Physical, sexual and psychological violence perpetrated or condoned by the State, wherever it occurs.

The global picture of violence against women is quite alarming and pervasive as per the statistics available. According to Funk et al (2005), in South Africa, 52,733 rapes and attempted rape cases were reported to the police between April 2003 and March 2004; in Zimbabwe, domestic violence accounts for more than $60 \%$ of murder cases dealt with by the high court in Harare.

In a 10-country study on women's health and domestic violence conducted by the World Health Organisation (2009), it was revealed that between $15 \%$ and $71 \%$ of women reported physical or sexual violence by a husband or partner. Many women, that is, $24 \%$ in rural Peru, $28 \%$ in Tanzania, 30\% in rural Bangladesh, and $40 \%$ in South Africa said that their first sexual experience was not consensual. Between $4 \%$ and $12 \%$ of women reported being physically abused during pregnancy.

According to Bloom (2008), violence against women and girls causes pain, disability and death to a number of individuals every day in every country in the world. The discourse explains that violence against women is a human rights violation. The United Nations Declaration on the Elimination of all forms of Violence against Women in 1993 (UN, 2003) mentions physical, sexual and psychological violence as the most common forms of violence that women face in their day to day life. According to Amnesty International (2005), at least one woman in every three has been beaten, coerced into sex, or otherwise abused in her lifetime. In Egypt, at least $28 \%$ of women have been slapped before (United Nations Statistical Commission, 2009) while in Kenya 83 percent of women have faced childhood physical abuse and 61 percent as adults in their life time (UNIFEM, 2009)

The commonest form of violence that women are confronted with in society today is intimate partner violence. This kind of violence is perpetrated by a husband or other intimate male partner. Physical and sexual violence are the most prevalent forms of intimate related abuses against women (Watts and Zimmerman, 2002). The study explains that in an African country like Zimbabwe, $26 \%$ of women who had ever been married reported being forced to have sex 
when they did not want to. The survey revealed that $23 \%$ reported physical force, $20 \%$ reported that their partner shouted, $12 \%$ reported being forced while they were asleep, and $6 \%$ reported the use of threats

According to Sherris (2002), Violence against women occurs in every country but most common within cultures where gender roles are strictly defined and enforced; where masculinity is closely associated with toughness and dominance and punishment of women are never frowned upon. In this setting, violence is a standard way to resolve conflicts. The study observes that violence perpetrated against women in many ways has lead to injury, fear, deadly diseases like HIV/AIDS and sometimes death.

\section{Current Situation in Africa}

Violence against women in Africa is a common phenomenon and Alokan (2013) explains that Cases of domestic violence against women have been on the increase in Nigeria with about $50 \%$ of women reporting being battered by their husbands. Often, the effect of such violent acts results in injuries and some loss of lives. The study further reveals that in some Muslim communities in Nigeria, violence perpetrated against women in marriage is not considered as an offence and often condoned and tolerated by society. Unfortunately, such violent acts have lead to serious health difficulties in the life of the victims.

According to Thaler (2012), South Africa has the highest rate of intimate partner violence against women in the world. The study asserts that young people in South Africa are frequently exposed to violence within their own families, with $26 \%$ of urban youths exposed to violent family disputes, almost $40 \%$ of which involved weapons. In its assessment of the prevalence of violence against women on the African continent, the United Nations Economic Commission for Africa (2007) reports that violence against women is a common phenomenon in almost all the African countries. However, the breeding ground for the perpetration of violence against women differs from country to country. Common among them however include a war situation, famine, dominance of patriarchal culture, traditional practices, relaxed penal systems and remote factors such a conscious attempt to subdue women by the use of violence.

A study by Khasakhala-Mwenesi (2004) in Kenya stated that about twenty-six percent of ever-married women reported having experienced emotional violence by husbands, 40 percent report physical violence, and 16 percent report sexual violence. Almost half (47 percent) of ever-married women report suffering emotional, physical, or sexual violence, while 8 percent have experienced all three forms of violence by their current or most recent husband. Young ladies as young as 15 years are subjected to multiple incidents of violence and often, it results in physical injuries, unwanted pregnancies, permanent emotional trauma and occasionally some die as a result

\section{Problem Statement}

The power of the media in influencing opinions and attitudes is a view shared by Anderson et al (2001) and Kafiris (2005). They explain that the media is an agent of change in the social structure and reflects happenings in our social world. However, Baker (2007) posits that the media portray reality of our social world except that these realities are recreated and represented. 
Portrayal of violence against women in the media is met with such contention among scholars. According to Onyejekwe (2004) and Pauwels (2008), portrayal of violence against women in movies is a reflection of the violence that are perpetrated against women in our societies and these visual images help us to understand our social world.

Srivastva and Agarwal (2004) on the other hand argue that portrayal of violence against women in movies is not merely a reflection of the reality in society rather, a creation of the media to normalise violence against women.

Afele (2006) investigated the portrayal of violence against women in Nigerian movies and upheld the position that violence against women in Nigerian movies reflects incidents of violence women suffer in Nigerian societies.

A study by Ardayfio-Schandorf (2005), Cantalupo (2006) and Bashiru (2012) established that violence against women existed in Ghanaian communities and it manifested in sexual, physical and psychological forms.

This study therefore seeks to investigate whether the portrayal of violence against women in Ghanaian movies reflect the forms of violence perpetrated against women in Ghanaian communities as established by Ardayfio-Schandorf, Cantalupo and Bashiru or it is merely a creation of the media.

\section{Objectives of the Study}

According to the Media Education Foundation (2005), media violence has not just increased in quantity but has also become more graphic, sexual, and sadistic. A report by Kaiser Family Foundation (2003) explains that as people continuously watch violent scenes on television, they become desensitized to violence, (that is, becoming more accepting of violence in real life and less caring about other people's feelings).

A study by Srivastva and Agarwal (2004) supports this position and argue that the visual media, be it television or cinema, is a very powerful vehicle for communicating ideas and images and that the visual media cannot be absolved of the blame of desensitizing human minds to violence. The claim that the media portray violence including violence against women is a point of convergence among these studies. However, whether these portrayals are merely a reflection of reality or a conscious attempt to recreate and re-present images of violence against women in movies is what divide opinion on the subject.

In investigating the portrayal of violence against women in Ghanaian movies, the researcher seeks to;

1. To ascertain the forms of violence that are portrayed in Ghanaian movies against women.

2. To examine how these forms of violence against women manifest in Ghanaian movies.

3. To examine the relationship between violence portrayed against women in Ghanaian movies and that which happen in Ghanaian societies. 


\section{Research Questions}

The research seeks to answer the following questions:

1. What forms of violence are portrayed in Ghanaian movies against women?

2. How do these forms of violence against women manifest in Ghanaian movies?

3. What is the relationship between violence portrayed against women in Ghanaian movies and violence against women in Ghanaian societies?

\section{LITERATURE REVIEW}

The review of literature in this chapter addresses some of the issues outlined by earlier scholars and researchers on the subject matter under discussion; movies and violence against women. The researcher delves into the broad subject of violence in the media and the issue of portrayal of violence against women in movies and the media in general.

\section{Violence Against Women}

The issue of violence in general is so complex and pervasive that its eradication is almost an illusion rather the approach in many years across the globe has been to respond to it (krug EG et al, 2002). The effect of this menace to society is so damaging that about 1.6 million people lose their lives to violence every year (ibid). Khasakhala-Mwenesi et al (2004) observed that common to all forms of violence that confront the world today is gender based violence and argued further that this challenge often stands in the way of development in any country. The discourse points out that, women are at the heart of any form of gender based violence and this often results in injuries or death. The report established that women of all ages suffer violence in various forms but the most prevalent is spousal violence where the woman is often battered for an offence which may be trivial.

According to Kameri-Mbote (2000), violence against women is a common feature among the rural folks in native Kenya. The study mentions culture as the primary tool for perpetuating violence against women. Cultural practices ensure that the woman is subdued; leaving all the powers of control in the hands of the man. Justification is always given for battering a woman when she attempts to challenge the status quo. Kameri-Mbote (ibid) points to a belief in historical values handed over to every generation where the role of the woman is clearly defined and any attempt to cross the boundary is met with victimisation from the entire society.

Cruz \& Klinger (2011) explain in a study that violence against women is dehumanising and oppressive and established that gender based violence is the major cause of pain and suffering among women and creates serious health consequences for the woman. The study identifies the female sexuality as the main conduit for perpetrating acts of violence against women. Sex violence is not only the most common acts of violence perpetuated against women but it also chips away their pride and self worth. Christie et al (2001) consented that violence against women indeed is a social canker and further argue that structures within our society fuel these acts. Their study posits that the dominant male structures within our societal set up continue to relegate women to the background, subduing them and victimising them in the process. 
Jewkes (2002) share the position that too much power in the hands of men greatly contribute to violence against women.

According to Jewkes (ibid), there is a link between alcoholism and violence against women. The study explains that alcohol inhibits good judgement and men who take alcohol as their past time usually brutalise their partners at the least provocation. Besides alcoholism, the study identifies poverty as another vehicle for perpetuating violence against women. The stress associated with poverty occasionally causes men to lose their cool and vent their spleen on their partners by subjecting them to multiple inhuman treatment.

In discussing the issue of violence against women, Kaufman (1999) argued that the prevalence of violence against women is basically as a result of unfair power distribution between men and women in society. The study further identified the main catalysts of violence against women in society; patriarchal power, the sense of entitlement to privilege, permissive attitude of social, religious and cultural norms to act violently towards a woman, the inherent feeling of dominance from birth as a man and past experiences from the home where women were beaten at will for the slightest error they commit.

Violence against women in societies is not merely a social canker but according Kharboush et al (2010) it has a lot of health related consequences. Their discourse on the health status of most women in Egypt who have experienced spousal violence showed that their health condition was so critical that some even die as a result of the multiple injuries they sustain. The WHO (2012) reports that women who have experienced physical or sexual violence in their life time are likely to have some chronic diseases such as memory loss, poor health, chronic pain, abdominal pain and frequent headaches. The report observes that between $15 \%$ $17 \%$ of unwanted pregnancies have come about as a result of sexual violence by a male partner. This has resulted in women doing abortion which in some cases lead to loss of lives.

A study by Fraser (2003) in a rural community in Australia revealed that on the average, women who suffered violence sustained three different types of injuries; $92 \%$ of the women reported cuts, scrapes and bruises; $11 \%$ broken bones and fracture and 3\% gunshot or knife wounds. The study posits that there is a link between violence against women and HIV/AIDS. Women who find themselves in violent relationship and are forced to engage in sexual intercourse and being unable to negotiate condom-use for fear of abuse contract such sexually transmitted diseases.

\section{Sexual Violence against Women}

According Planty (2013) sexual violence is unwanted sexual contact between a victim and offender. Sexual violence may or may not involve force and include grabbing or fondling or verbal threats. Neuman (2013) studied the prevalence of sexual violence against women in India communities and points out that sexual violence is common in all India societies; from the upper class to the lowest income earning group. The study posits that sexual violence is one of the ways where men show their authority over women and the society sees it as a normal phenomenon. Women who are victimised refuse to report incidents of such violent acts and overtime have come to accept the phenomenon as normal. Myhill \& Allen (2002) in a survey established that around 1-10 women said they had experienced some form of sexual victimisation since the age of 16 while between 1-20 women said they had been raped on at least one occasion since age 16 . 
A study by the Harvard Humanitarian Initiative (2009) revealed that sexual violence is most prevalent in many communities in the Democratic Republic of Congo. These violent acts took the form of rape of both young and old, forced incest, gang rape, rape in public and rape with foreign objects. The study pointed out that most of the principal actors were armed warlords. The war situation that bedevilled the country created a lawless society, thus creating an environment for such acts to be committed without fear of any punishment.

Amenu \& Hiko (2014) conducted a study to investigate the prevalence of sexual violence in Kenya. The study revealed that, sexual violence against women is on the increase and it affected young girls between the ages of 15 and 19 who are living in single parent households, grandparent headed households and women who are separated or divorced. About $79 \%$ of the offenders of these acts against women were people known to the victim and often the act takes place in the perpetrators own home.

A report by the WHO (2010) revealed that the health challenges associated with sexual violence may be long lasting or fatal. Sexual assaults results in unwanted pregnancies and often the act is perpetrated by men known to the victim. The report points out to a link between alcohol consumption and perpetration of violence against women.

According to Donohoe (2004) sexual violence against women often go unreported or certain delay in reporting the matter to the law enforcement agencies. The study revealed that in developing countries like South Africa, rape was a common feature and as many as 50,000 rape cases occur in the streets and ghettos of South African communities. In places like Ghana, Benin and Togo, there is a belief among some traditional heads that having sexual intercourse with a virgin can cure diseases such as HIV/AIDS. Shrines manned by old men sexually exploit young laden resulting in multiple health challenges for the victims. A study by Sampson (2004) among college students in the United States of America revealed that one of the most common of sexual violence perpetrated against the women is acquaintance rape. These include gang rape, date rape, which usually takes place in the victim's home or in a car, rape in a non-party and non-date situation such as while studying together, rape by a former intimate or a current intimate.

\section{Rape}

Rape is defined as any form of sexual intercourse without free mutual consent between those involved .Sexual intercourse that involves force, threat, blackmail, deceit or coercion is rape - even when there is no penetration. (Esere et al 2009). The study by Esere et al (ibid) explains that rape is a common form of violence among intimate partners but established that rape that occurred in marriages are not considered as an offense irrespective of the injury the woman suffer in the process. Marital rape indeed is not considered rape at all.

Among adult women surveyed in 2010, 26.9\% of American Indian/Alaska Natives, $22 \%$ of non-Hispanic blacks, $18.8 \%$ of non-Hispanic whites, $14.6 \%$ of Hispanics, and $35.5 \%$ of women of multiple races experienced an attempted or a completed rape at some time in their lives. (National Center for Injury Prevention and Control, 2012). A survey conducted by Statistics South Africa (2000) revealed that rape is prevalent in most south African communities hinting that the perpetrators of the crime often use weapons to threaten the victims into submission. A study by Mabasa (2009) identified child rape, elderly rape, intimate partner rape and gang rape as the forms of rape incidents common in African 
communities. The study mentioned that while perpetrators are persons known by the victim, most victims are simply unwilling to report such cases to the police.

\section{Sexual Assault}

Sexual assault is defined as a crime that includes attacks or attempted attacks generally involving unwanted sexual contact between a victim and offender. Sexual assault may or may not involve force and includes grabbing or fondling. Sexual assault also includes verbal threats. (Langton et al, 2013). In 2007 Police reported that in 82\% of sexual assaults, the victim knows the perpetrator and in $18 \%$ of incidents, the accused was a stranger to the victim. $31 \%$ of accused are family members, $28 \%$ are casual acquaintances, $8 \%$ were identified as friends, $6 \%$ were identified as authority figures, 5\% were current or former boyfriends/girlfriends $4 \%$ were business acquaintances. A study by Petersen et al (2005) revealed that violence against women and girls such as sexual assault, is a common method for enforcing discipline and control over women in South Africa. Such forms of violence are viewed as acceptable ways of solving conflicts, gaining power and inflicting punishment

\section{Incest}

Van Niekerk (2005) in a study acknowledges that one of the forms of violence against women is incest. The study defines incest as 'any sexual contact or behaviour for the purpose of sexual stimulation, between an adult (and another child in a position of power over the victim) and a child related within a family structure. This child can be related biologically, can be an adopted or stepchild or can be a child under the guardianship of the incest perpetrator. The sexual contact can include contact such a sexual fondling, indecent exposure, masturbation, hand-genital contact, oral-genital contact, or intercourse, as well as such activities as showing erotic materials or making sexually suggestive comments to a child'

\section{Defilement}

The offense of defilement is defined under the section 101 of the Criminal Offenses Act, 1960 (Act 29), of Ghana as the natural or unnatural carnal knowledge of any child less than sixteen years of age. Section 101(2) of the Criminal Offences Act, 1960 states that:

A person who naturally or unnaturally carnally knows a child under sixteen years of age, whether with or without the consent, commits a criminal... (Morhe \& Morhe, 2013)

\section{Physical Violence against Women}

Physical violence is one of the commonest forms of violence that women suffer from an intimate relationship. Nnadi (2012) reports that physical violence against women in Nigeria communities is common place. Women are battered in relationships resulting in serious health implications and worse of all the Penal Code of Nigeria which is applicable in the predominantly northern parts of Nigeria also validates wife beating. The reports points to lack of political will to punish perpetrators of these heinous crimes. Ashimolowo \& Otufale (2012) in their assessment of domestic violence against women in Ogun state, Nigeria, revealed that about $81 \%$ of married women admitted having been verbally or physically assaulted by their husbands before. Though the study did not explore the types of physical 
violence that the women suffer, it established the lack of interest by the battered women in reporting the matter to any law enforcement agency.

\section{Wife Beating}

One of the ways by which women a physically abused is through severe beatings by a partner and this is acknowledged Noah (2000) in his study of the types of violence women suffer in some Nigerian communities. The study established that women who are often abused physically are often battered by their partners for issue that appear trivial.

\section{Stabbing}

The WHO (2012) mentions stabbing as one of the types of physical violence women face mostly in an intimate partner relationship.

\section{Pushing}

Pushing of a victim is acknowledged by WHO (2012) as a form of physical violence perpetrated against women in intimate partner relationships

\section{Shooting}

The WHO (2012) identifies shooting as a type of physical violence that men unleash on women in an intimate partner relationship and this may be fatal in some cases.

\section{Kicking}

Kicking of a victim is acknowledged by WHO (2012) as a form of physical violence perpetrated against women in intimate partner relationships

\section{Psychological Violence}

According to Donohoe (2004) the aftermath of physical or sexual violence usually result in psychological consequences such as shock, humiliation, anxiety, depression, substance abuse, suicidal thoughts, loss of self-esteem, guilt and sexual dysfunction. Such aftershocks according to the study, usually distabilises the victim perpetually live in psychological trauma.

\section{Portrayal of Violence against Women in Movies}

Portrayal of violence in the media has been an age old debate among scholars. The admission that the media portray violence has been a point of convergence among various studies. However, differences emerge where the issue of effect is thrown into the argument. A study by Kaiser Family Foundation (2003) posits that, viewing of television violence can lead to some effects including increased aggressive behaviour and desensitisation to violence (that is, becoming more accepting of violence in real life and considering such violent acts as a normal occurrence in life.).

This position is supported by Anderson et al (2003). Their study asserts that exposure to violence in the media increases violent crimes in real life. The views of Savage (2004), Funk et al. (2004) and Ferguson (2009) on the contrary, depart from the position that media violence has the effect of influencing people to act aggressively in real life. Savage, for 
instance, argues that the relationship between media violence and aggressive behaviour is more of perspectives rather than the weighted evidence. This position is what is shared by Funk et al. and Ferguson.

Portrayal of violence in the media is again criticised by Okunna (2002), Crouteau and Hoynes (2003) and Srivastva and Agarwal's (2004) for reinforcing and normalising violence and ostensibly providing the model for behaviour. The mode by which the media reinforces and normalises violence is not explicitly stated in these studies except the allusion that continuous exposure desensitises the mind of the viewer and tends to see violence as a normal occurrence in real life. Pauwels (2008) on the other hand, holds a different view on the effect of media content as a whole.

The study by Pauwels explains that media images and visual representations of all kinds contribute to the understanding of our social world. The visual media thus, reflect and create societal 'reality' and though it does not provide direct access to reality, but at best it offers possible 'versions' of a reality that can never be grasped and known in its entirety. The contention however is whether media text simply reflects reality as posited by Pauwels (2008) or it goes beyond mere representation to reinforcement and normalisation of violence as portrayed in the media.

The movies are a microcosm of the media and portrayal of violence in movies is a reality (Larasi 2012). According to Lewis et al (2010), the movies are one form of the media in which the youth is exposed to violence. The discourse explains that movies contain heavy doses of violence in recent times and has the capacity to desensitise violence in the minds of the viewers. Further, the report argues that the primary reason why violence was introduced in movies was to deter society from such violent behaviours but admittedly as stated in the report, the motive for the portrayal of violence in the movies has back fired. Lewis et al advances the argument that an effort to control media content in relation to portrayal of violence has also been a challenge. In fact, Heins (2001) posits that violence is an eternal theme in literature, art, popular entertainment and games invented by children at play. Effectively, this assertion conveys the notion that movies and violence are somewhat inseparable.

Violence portrayed in movies is in various forms. Violence portrayed against women in movies is one of such and has been described by Larasi (2012) as problematic. The study explains that throughout the media, women are consistently portrayed as sexual objects available to men. Thus, the open objectification of women coupled with misrepresentation and sensationalism portrays the woman in a negative light. Okunna (2002) discusses the issue of portrayal of violence against women in Nigeria video films and makes the point that these movies portray the woman in a negative light. He asserts that though viewers of the video films acknowledge that the extremely negative portrayal of women in the films is unrealistic, the effect however is that it can increase men's disdain for women and strengthen the forces which push women to the background in this patriarchal society.

Violence against women is a reality which confronts us on a daily basis in communities all across the globe. However, in relation to the portrayal of violence in movies and the media in general, the quandary is whether these portrayals in the media are merely a reflection of the reality that confronts us on a daily basis or a misrepresentation of the reality to reinforce acts of violence as espoused by Srivastva and Agarwal (2004). Commenting on the issue of 
portrayal of violence against women in the media, Onyejekwe (2004) argues that violence against women as portrayed in the media is a reflection of the reality but at the same time these portrayals reinforce acts of violence against women. The study points out that these portrayals convey some sense of reality but the construction of the message leaves many questions unanswered.

At the heart of portrayal of violence against women is how women are generally positioned in movies. According to Parvez and Roshan (2010), the images projected about women in movies always position them as losers. They are always devalued, emotionally traumatised or projected as inferior figures. This view is supported by Das (2012) and explains that women are still being depicted as weak, frail and sometime manipulative in films and soaps. Indeed, Onyejekwe (2004) admits that the portrayal of violence against women in the media is quite disturbing and further argues that even when they become victims of violence they are projected as helpless victims on the screen.

One concern about media portrayal of women is how they are positioned as objects of victimisation. The objectification of women in movies and the media in general is a concern shared by Stankiewicz and Rosselli (2008) who argue that women are not only depicted as sex objects on the screens but as victims too. Their study explains that sexual victimisation of women in movies is worrying and may have the propensity of influencing behaviours. In analysing how the media portrays women, Berberick (2010) calls the representation of women in the media as exploitative. The discourse points out that throughout the years, the media has reduced women to being nothing more than objects to be won, prizes to be shown off, and playthings to be abused.

\section{Violence against Women in Ghana}

Violence against women is perceived as a global canker and in Ghana, studies by ArdayfioSchandorf (2005) and Coker-Appiah and Foster (2002) have revealed that women in Ghana suffer some forms of violence in the home and the society at large. Appiah and Cusack (as cited in Afele, 2006) identified three main forms of violence suffered by women in Ghana; namely, physical, sexual and psychological. The study showed that in Ghana, 33\% of women have been physically abused before while $27 \%$ of women have also suffered sexual violence one way or the other in their lives. The study further argued that for 2 in 10 women in Ghana, their first experience of sexual intercourse was by force, 2 in 5 women are harassed or coerced when they refuse their partner sex, and 3 in 10 women are forced by their male partners to have sex sometimes.

In a study to appreciate some of the causes of violent behaviour perpetrated against women in the Ghanaian setting, Coker-Appiah and Foster (2002) found out that violence against women is influenced by social attitudes and values which see men as naturally superior to women and make it a man's right and responsibility to control a woman's behaviour. The study explains that in the Ghanaian society, what is considered acceptable behaviour is determined by the man and society and failure by the woman to comply with the socially acceptable behaviour leads to violence.

According to Jensen (2006), some traditional practices in Ghana such as Trokosi (a traditional practice where young virgins are sent to shrines of priests in reparation for the misdeeds of family members) among the Ewes in the Volta Region tends to perpetuate violence against 
women. The study explains that the priest to whom these young girls are sent to, assumes full ownership of these young girls, beating them when they try to escape, controlling their interaction with others, demanding labour and sex from them, and denying them education, food and basic health services.

A study conducted by Ardayfio-Schandorf (2005) in a rural community in Ghana showed that violence against women occurred in sexual, physical and psychological forms. These manifested in a form of wife beating, rape, defilement, dowry related violence, psychological trauma and economic deprivation. According to the study, at least $23 \%$ of women have been beaten by their husbands or boyfriends before; $6 \%$ said they have been defiled before while another $8 \%$ said they have been raped before.

In explaining the forms of violence that confront women in the Wa community in Ghana, Bashiru (2012) identified sexual violence as the most common of violence that occurred in this community. Poverty, cultural practices and the general distribution of power between men and women largely contribute to the perpetration of violence amongst the rural folks. Forms in which these acts manifested included rape and defilement. A rare situation though consistent with most occurrences in African communities is the lack of will on the part of the abused women to report to appropriate agencies for redress.

According to Cantalupo (2006), one of the primary reasons why women are victimised in Ghanaian communities has to do with the stereotypical roles they have been assigned to. The study points out that it falls within the right of the man to discipline a woman for any act of misdemeanour. The right to discipline takes the form of beating and because the act is viewed as a way of bringing sanity in a relationship, the society at large condone this act and somewhat lend their support to it. Again, women are often beaten and raped by their husbands when they refuse to sexually satisfy them. Refusal on the part of the woman to be sexually available to the husband usually comes as a result of infidelity on the part of the man who apart from his wife has other mistresses he pays attention to.

\section{Media Portrayal of Violence against Women}

In a study by the Parents Television Council (2009), it found out that violence against women on television is on the ascendency. They discovered that violence against women in the United States of America had increased by 120\% between 2004 and 2009.

The study further established that the most frequent types of violence against women on television was beating (29\%), followed by credible threats of violence (18\%), shooting $(11 \%)$, rape $(8 \%)$, stabbing $(6 \%)$, and torture $(2 \%)$. Violence against women resulted in death $19 \%$ of the time. Violence towards women or the graphic consequences of violence tends, overwhelmingly, to be depicted (92\%) rather than implied (5\%) or described (3\%).

The media indeed in recent times has come under scathing attacks for how they portray women generally and according to Made (2008), when women do appear in the media, they most often are 'portrayed as sex objects, beauty objects, homemakers, victims (of violence, poverty, natural disasters, war and conflict, etc.); or they become front-page and headline (main story) news when they engage in activities which are not in line with society's prescription of what women should and should not do'. 
In interrogating why the media portrays women in such negative light, Marshall (2004) observes that the sexual brutalisation of women as portrayed in the media is a highly marketable business, bringing in some $\$ 10$ billion in profits in the U.S. every year.

Again, Marshall argues that men's violence against women is treated like a "dog bites man" story, and women's violence against men as a "man bites dog" story. Otherwise meant to be an offence against women, the media views violence against women as a normal occurrence of life and needs little or no attention at all. In this light, women continue to be seen as objects of victimisation by men and this canker is reinforced by the persistence and continuous portrayal of women as victims of society.

\section{Portrayal of Violence against Women in the Ghanaian Media}

Croteau and Hoynes (2003) have argued that the mass media has changed the old notion of globalisation where human beings are connected only in relation to their physical location. With the advent of popular media, globalisation has gone beyond boundaries and this has paved way for other cultures to infiltrate others with the dominant ones eventually becoming the popular culture of the people. Their discourse explains further that the reality of other cultures being dominant in our society was aided by television. The media thus has become that platform which allows the infiltration of other popular cultures into other countries. Movies as a microcosm of the media are one avenue for popularising these cultures.

Afele (2006) acknowledges this development and underscores the point that the media in Ghana in recent times portray graphic scenes of violence against women. The study argues that ordinarily, such portrayals were not common place features in media programming in Ghana but with the advent of globalisation, other cultures have infiltrated ours through movies and other media outlets.

\section{THEORETICAL FRAMEWORK}

\section{Stereotyping}

Stereotyping has been explained variously by different researchers and they all agree that these are biases that society develops which can lead to an erroneous perception about the world. According to McGarty et al (2002), stereotypes are rigid and distorted mental structures that lead people to make serious errors; Stereotypes are false or misleading generalisations about groups held in a manner that renders them largely, though not entirely, immune to counter-evidence (Blum, 2004); stereotypes are simplified, fixed beliefs about a group of people (Aguilar, 2006); and Ibroscheva and Ramaprasad (2008) say that Stereotypes are overgeneralisations about members of a social group.

Again, researchers argue that stereotyping has become aids in understanding the roles of gender in our society. According to Prentice and Carranza (2002), gender stereotypes are highly prescriptive and have become cues that guide our understanding of one group over the other. Their study mentions that the quality stereotyping ascribes to men and women tend to be one required of men and women in society. Cuddy et al (2010) in a study explains that the traits that are perceived as uniquely characteristic of men and women turn on the dimension of independence-interdependence. Prentice and Carranza argue again that gender stereotype 
is closely linked to traditional social roles and power inequalities between women and men. These then affect important social life outcomes such as the perpetuation of violence against women.

Stereotyping of women has been a major concern with media researchers. Various Studies have dealt with the forms by which the media portray women. Kaul and Shradha (2010) identified sex-stereotyping as one of the deeply woven images of women in television movies in recent times and argue that these portrayals do not depict the reality of women's role in society. The study posits that the continual portrayal of women in stereotypical cues such as unintelligent, weak and victims of aggressive behaviour on the screens are likely to have an impact on the thinking pattern of society. Jordaan et al (2011) support the assertion that television and the movies continually draw the line between feminine and masculine roles where the former is portrayed on the screens as sex objects and always positioned as a weak figure. Their discourse points out that the portrayal of gender roles in the media are authenticated through regular exposures and then adopted by the public as the norm.

Stereotyping of gender brings about the conferment of right, power and authority on one group as against the other (Cuddy et al, 2010). Prentice and Carranza's study makes the point that men are seen as embodying traits such as arrogance, aggressiveness, being assertive and insensitive while women embody traits such as caring, weak and gullible. The inequality created by traits-stereotyping between the gender, results in a power struggle between men and women in society (Tracy, 2007). The study by Elias (2008) reveals that the continuous power struggle results in the abuse of women. Again, the study by Elias explains that the ultimate cause of all abuse against women is patriarchy. This manifests as abuse, violence against women, disrespect, control of sexuality and women's bodies, objectification and beauty standards, and the devaluation of women's contributions, views and opinions'

The image and representation of women in the media and the movies in particular has long been a subject of concern. According to Wright (2005), the media plays an influential role in creating images of both women and men and our appreciation of gender roles in society could largely be attributed to the workings of the media which has also become the platform for perpetuating stereotypical images about women.

The visual media constantly portray women in the home, performing domestic chores such as laundry or cooking; as sex objects who exist primarily to service men; as victims who can't protect themselves and are the natural recipients of beatings, harassment, sexual assault and murder (Kaul and Sahni, 2010). These media messages do not only give people information and entertainment, but, it also affects people's lives by shaping their opinions, attitudes and beliefs.

Moreover, due to the media's great influence on people's attitudes (Ibroscheva and Ramaprasad, 2008), they can depict certain social groups in negative and unrealistic manner and as people become more dependent on the media for their information about the world, the possibility for erroneous images of the world increases greatly (Blum 2006). According to Crouteau and Hoynes (2003), media messages are packaged to create a certain image of reality, which is consistent with the policy of the dominant group. Reflection of a real world therefore becomes incomplete and distorted. (Kellner, 2002; Novak, 2005). 
In a study to understand Audience perception of portrayals of women in Nigerian home video films, Azeez (2010) agrees that the visual media portray women in stereotypical roles. The study argues that Nigerian films portray and position Nigerian women stereotypically and negatively. The representation of women in the films is such that they are positioned at the bottom of the power hierarchy in a way that reinforces their domination and suppression. Citing Shivdas (2004) in a study of gender portrayal in the media, Onyejekwe (2004) explains that violence against women in films takes the shape of rapes, spousal abuse and sometimes public humiliation of fallen women. According to the study, these portrayals convey some sense of reality but the construction of the message leaves many questions unanswered.

Supporting these positions, Baker and Cunningham (2005), say that stereotypes of male and female roles are prevalent in movies and on television and these stereotypes suggest that men are aggressive and in control and women are passive, submissive, sexually available, and eager to cater to the needs of men. Again, the discourse propounds that the media portrayals of violence may be presented as normal, deserved by the victim, and executed without consequence. The study holds the assertion that portrayals of women in films and on television suggest that we collectively see women as legitimate targets of violence.

\section{Feminist Film Theory}

The feminist film theory is born out of an attempt to reframe the negative portrayal of women on the screen. Stereotypical images of women in films and the object of 'male gaze' are central to the feminist film theory. This theoretical perspective that underpins the present study was first started by in 1975 with his concept of the male gaze. Mulvey's argument is basically this: representation and spectatorship of women in the cinema is organized along gender lines, creating an active (male) spectator in control of a passive (female) screen-object

Wales (2002) explains that Mulvey's concept of male gaze sees the representation of women in films as being dominated by a male point of view. The men play active roles in films while the women the passive roles. Eventually, the woman is portrayed as an object for the pleasurable viewing of the male audience.

The work of Mulvey injected freshness and a new perspective in feminine film study. The representation of women in films and the construction of reality in cinema has been the contention of feminine film criticism. Feminine film critics seek to challenge the image of women in movies with the aim of exposing the ideological operations of patriarchy. According to McCabe (2004), representation of women in the cinema is one of the key issues that most feminine film critics rally around. Her discourse points out how film is read as text but with ideological undertones intricately linked to patriarchal values and opinions. The discourse highlights the concerns of feminists; pointing out how the filmmaking practices transmits ideological codes of patriarchy to construct an image of woman as somehow fixed.

Berberick (2010) defends the position that the representation of women in the media has always been exploitative. The discourse establishes the point that over the years, the movies have reduced the woman to being nothing more than objects to be won, prizes to be shown off, and playthings to be abused. With the heavy doses of patriarchal influences in cinema today, feminist film theorists question the representation of women in films. The image of 
women is constructed along the lines of patriarchal codes and this reinforces the long held status quo of male dominance (Stam et al, 2005).

In relation to portrayal of violence against women in movies, Atakav (2010) argues that violence against women often recurs in the representation of issues around women or women's experiences in patriarchal cultures. The study explains that the existing patriarchal structure in filmmaking continues to portray the woman as an object of victimisation on the screens.

Indeed, at the core of this theory is the grave concern expressed by feminist critics of how the movies misrepresent the female figure as weak and helpless and solely derives its existence from the support of a man's strength. These portrayals in movies, according to the film theory, negatively position the woman in a manner that makes her an object of abuse by their partners.

According to Chaudhuri (2006), underlining the feminist film criticism is a sociological perspective which explains that the image of women in movies is distorted; portraying a different picture of who women are in real life. These distortions according to the study are organised and constructed along masculine view point; focusing on negative female stereotypes.

\section{METHODOLOGY}

This chapter covers an overview of the methodology used in investigating the Portrayal of Violence against Women in Ghanaian Movies. The research design is outlined and catalogued in detail, as well as the sampling strategies employed, data collection and data analysis procedures. Included in the discussion are measures employed to establish the trustworthiness of the study.

\section{Research Design}

A research design is the framework or blueprint for conducting a research study. It details the procedures necessary for obtaining the information needed to structure or solve a research problem (De Vaus, 2001). The use of content analysis in this study was not only to count the manifest textual elements but also to explore the meanings underlying physical messages. The process involved sampling of data purposively and developing unique themes that manifest in the movies in order to illustrate the range of the meanings of the phenomenon rather than the statistical significance of the occurrence of particular texts or concepts.

Research Approach

The approach used in this study to address the research problem was predominantly qualitative. The use qualitative methodology was to provide a frame work to explore, describe and explain the phenomenon under study to enhance understanding of our social reality. The study relied on the qualitative research paradigm also because it was more suitable an approach in helping to arrive at the objectives of the study. 


\section{Population}

The population of a study includes all the elements or objects that meet the criteria for inclusion in the study (Castillo 2009). The population for this study from which the sample is selected is Ghanaian movies. The scope of the study was within the Ghanaian context. Therefore, all movies selected and used for analysis were all Ghanaian movies.

Sampling Frame

The difficulty of accessing records on Ghanaian movies coupled with the absence of box office statistical records made it difficult for the researcher to settle on the sampling frame. However, the researcher settled on movies listed for 2011 Ghana movie awards. The movies nominated for the awards span one calendar year from January to December 2011. The choice of year was for the purpose of currency and its relevance to the study. Again, the Ghana Movie Awards Scheme was an option for the researcher because it provided a categorization structure that made it relevant for the researcher to select movies from a category most suitable for the study.

\section{Sampling Approach}

The researcher purposively chose the Best Story category out of twenty eight other categories listed for the 2011 Ghana Movie Awards. This category was of relevance to the researcher because movies nominated here according to the category description have the best storylines and represented movies with the best stories for the whole of 2011 in Ghana among other movies released during the calendar year. There were six movies in this category. The researcher conducted an exploratory preview of the movies to ensure that each selected movie had aspects of scenes of violence adequate for analysis. Three movies in all were selected for the study; Ties That Bind, Somewhere In Africa, and Death after Birth

\section{Data Collection}

The researcher purposively sampled three movies for the study; Ties That Bind, Somewhere In Africa, and Death after Birth. A coding protocol was developed by the researcher to serve as a guide in extracting information from the data in order to answer the research questions. The use of content analysis as instrument of measure in this study implies that some operational definitions of the concepts must be explored. In this context, I try to define the expression "violence" within the framework within which the study is conducted. In this direction, violence is defined as

The intentional use of physical force or power, threatened or actual, against oneself, another person, or against a group or community, that either results in or has a high likelihood of resulting in injury, death, psychological harm, maldevelopment or deprivation (WHO, 2002).

\section{Data Analysis}

For the purpose of this study, the researcher used qualitative content analysis. According to Zhang and Wildemuth (2009), qualitative content analysis involves a process designed to condense raw data into categories or themes based on valid inference and interpretation. This process of data analysis uses inductive reasoning where themes and categories emerge from the data through the researcher's careful examination and constant comparison. According to 
Elo and Kynga (2008), the aim of qualitative content analysis is to attain a broad description of the phenomenon in order to give an insight and understanding into occurrences within its context.

Three main categories in the study emerged; physical, sexual, and psychological violence. These categories are operationalised in the study to mean;

Physical violence - any overt depiction of physical force by a person to hurt a partner by hitting, kicking, or other type of physical force that causes or likely to cause an injury to the person. Sexual violence - any overt depiction of physical force on a partner to take part in a sexual act when the partner does not consent.

Psychological violence - any form of abuse aimed at chipping away your self-worth and independence. It manifests through name calling, yelling, blaming, and shaming, isolation, intimidation, and controlling behaviour.

According Mayoux (2000), the purposes of conducting qualitative research is to increase understanding of what is happening, contribute to understanding of who is affected in which ways, analyse why particular impacts are occurring and assessing how policy can be improved. These four cardinal principles espoused by Mayoux served as guide in the study in the analysis of the findings.

Variables for the Study

The study by Ardayfio-Schandorf (2005) on violence against women served as a guide to the researcher in developing the variables for this study. According to the study, violence against women in communities occurs in a form of wife beating, rape, defilement, widowhood rites, forced marriages, female circumcision and psychological abuse. The variables for this study included;

Physical violence - Beating, Pushing, Stabbing and Shooting

Sexual violence - Rape and defilement.

Psychological violence - Intimidation, Shaming, Isolation and Name Calling

Several variables pertaining to the entire film were measured, including the release date, running length (in seconds) and length of violence in a scene.

Unit of Analysis

The unit of analysis refers to the basic unit of text to be classified during content analysis (Zhang and Wildemuth, 2009). For the purpose of this study, the units of analysis are scenes in the movies. The researcher used scene by scene account as its basic unit because it was quite simple and lends itself to flexibility especially during the coding process.

\section{Coding}

The researcher together with two other undergraduate coders from the University of Ghana watched all the movies separately to code the various themes in the study. This exercise was to measure the level of inter coder-reliability. The researcher and the other coders all watched the film "Somewhere in Africa" to serve as a pre-test for coding and coder reliability. We 
coded for incidences of physical, sexual and psychological violence, implements of physical violence, duration of violent scenes, duration of violence, length of movie, perpetrators, victims and relationship between perpetrator and victim. The pre-testing recorded an intercoder reliability of $87 \%$.

Coding was done to ascertain the presence of a particular incident in a variable. The presence of incidents was scored as 1 under the respective variable. The multiples of 1 indicated the frequency of that incident in the movie. The duration of the movie was also determined after viewing the entire movie. Duration for incidents under the main variables was also determined by counting on incidence basis. Coders also used the forward and rewind mechanisms of the movie player to examine the accuracy of the duration of such incidents. The duration was counted in seconds. The variables under male and female were also counted in the multiples of one.

The two variables of perpetrators and victims were coded in relation to each defined incidence in the categorized variables. The data collected are presented through a frequency distribution table and subjected to analysis.

\section{Description}

The descriptive nature of this research is twofold; first, a step by step approach to the study of portrayal of violence against women in Ghanaian movies was explained to throw more light on the phenomenon under study. Secondly, the use of the coding scheme and the subsequent representation on a frequency table was to give the clearest picture of the phenomenon under investigation within the context of the study. In this regard, the descriptive component in this research answered the rate of prevalence of violence against women in Ghanaian movies that the study sought to measure.

Interpretation

Interpretation focused on the usefulness of the findings in relation to global efforts to combat all forms of violence against women (Millennium Declaration, 2000). The role of the media and movies in particular in the portrayal of violence against women and its implication for future policy direction is addressed in the study.

\section{Analysis}

The analysis component of the research explained in detail the relevance of the findings in relation to the meaning of earlier works done by other scholars. The analysis addressed some points of convergence of this study to other scholarly works as well as points of divergence. Again, the analysis was conducted within a theoretical framework adopted by the researcher. The analysis on findings provided a platform to enhance understanding of portrayal of violence against women in Ghanaian movies.

Trustworthiness

In order to achieve reliability, as well as, the validity of the study, the researcher gave a detailed description of every step in the research process. Insight of data was provided by the researcher throughout the study. Consistent with qualitative content analysis, the researcher 
relied solely on data within the context of the study. The coding protocols developed by the researcher also served as a check in collecting information within the context of the study.

Synopsis of Movies

\section{Death after Birth}

This is a chilling movie of a young lady, Zeneil, who suffered physical, sexual and psychological abuses from birth till death. She is a product of an incestuous act between father and daughter, a victim of sexual and physical abuses from her foster parents. She suffered from pain and torture at every stage of life. In a bid to purge herself of the chaotic experience she felt within, she resorted to violence. She made victims of those who traumatized her in the journey of life by subjecting them to multiple physical abuses in return. She charted the course of vengeance and made victims of many. Zeneil was sentenced to death for murder. Her experience in life was traumatic and her end was tragic.

\section{Ties That Bind}

The psychological scourge that women go through in their relationship is epitomized in the life of Adobea. She finds herself in a marriage that has seen her bury all seven of her children to unknown circumstances and she remained childless. Her mother-in-law calls her names and brands her a witch. Her childhood friend, Buki, a medical doctor, is posted to her village and she becomes her saviour and a help to the community at large. Although suffering from lung cancer, the warmth of friendship assuages her pain and saves Adobea from imminent death.

\section{Somewhere In Africa}

Somewhere in Africa is a thriller that recounts life under a dictatorial military regime in a town of Kambila. After a successful coup de tat, Yussif Gabiza, the leader of the uprising resorted to killing all persons believed to be enemies of the state. Victims included women and innocent school children. The regime maimed, raped and killed women at the instance of Gabiza, the leader of the junta. Although Gabiza, finally got killed in another uprising, he left behind scars of murder, rape and trauma in the land of Kambila. His victims were mainly helpless women.

\section{FINDINGS AND ANALYSIS}

This chapter presents the findings as well as the analysis of the study. The study sought to investigate the portrayal of violence against women in Ghanaian movies. The findings made by the researcher in this study showed the forms of violence against women that often occur in Ghanaian movies, the frequency with which these violent acts occur, the perpetrators and their relationship with the victims.

The presentation of findings in this chapter includes a numerical representation of the frequency of violence perpetrated against women in the Ghanaian movies. The counting of events in the movie that related to violence against women was presented in a tabular form for; 
a. Easy understanding of the scope of violence perpetrated against women in Ghanaian movies.

b. Easy description of the frequency with which violent acts perpetrated against women occur in Ghanaian movies.

\section{What Forms of Violence Are Portrayed In Ghanaian Movies Against Women?}

Three movies in all were used in this study; 'Ties That Bind', 'Somewhere In Africa' and 'Death after Birth.' In investigating the forms of violence that are predominantly portrayed in Ghanaian movies, the researcher discovered from the data that three main forms of violence occur in Ghanaian movies.

These are physical violence, sexual violence and psychological violence. These themes emerged from the data based on the different and varied forms of violence that were perpetrated against women in the movies. Graphic incidents of beating, stabbing, shooting and pushing were categorized under physical violence. Rape and defilement were classified under Sexual violence while Psychological abuses manifested in a form of intimidation, shaming, isolation and name-calling. The definition by the United Nations Declaration on the Elimination of Violence against Women (UN, 1993) and work by Ardayfio-Schandorf (2005) on Violence against women: The Ghanaian case; provided a guide in assigning the different variables under each respective theme as they emerged from the data.

An examination of the data used for the study revealed that physical violence is the most common form of violence against women portrayed in Ghanaian movies. The table below shows the cumulative frequency of forms of violence portrayed in Ghanaian movies.

Table 1: Cumulative frequency of forms of violence portrayed in Ghanaian Movies

\begin{tabular}{lccc}
\hline Movies & $\begin{array}{c}\text { Physical Violence } \\
(\boldsymbol{\%})\end{array}$ & $\begin{array}{c}\text { Sexual Violence } \\
(\boldsymbol{\%})\end{array}$ & $\begin{array}{c}\text { Psychological Violence } \\
(\boldsymbol{\%})\end{array}$ \\
\hline Ties That Bind & $2(50 \%)$ & $1(25 \%)$ & $1(25 \%)$ \\
Somewhere In Africa & $5(56 \%)$ & $2(22 \%)$ & $2(22 \%)$ \\
Death after Birth & $6(46 \%)$ & $3(23 \%)$ & $4(31 \%)$ \\
Total1 & $\mathbf{3 ( 5 0 \% )}$ & $\mathbf{6 ( 2 3 \% )}$ & $\mathbf{7 ( 2 7 \% )}$ \\
\hline
\end{tabular}




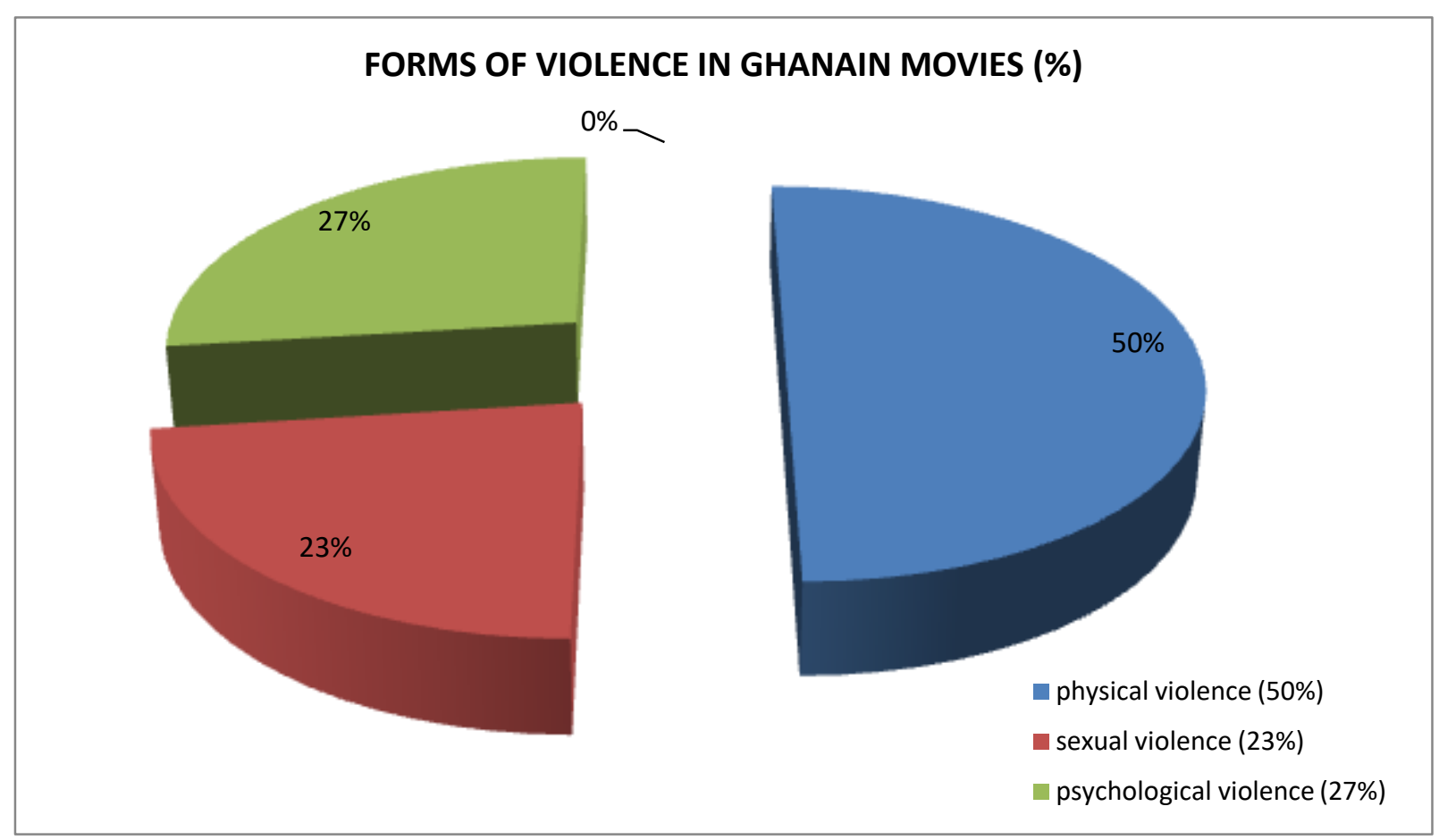

\section{Chart 1: Chart Showing the Percentage of Various Forms of Violence Portrayed In Ghanaian Movies}

Results in Table 1 above show that in all the movies studied, physical violence was the most common form of violence portrayed against women in Ghanaian movies. In 'Ties That Bind', physical violence accounted for $50 \%$ of all the violence portrayed against women, $56 \%$ in 'Somewhere in Africa' and 46\% in 'Death after Birth'. Portrayal of Psychological Violence against women in Ghanaian Movies accounted for $27 \%$ of all forms of violence against women while Sexual Violence accounted for $23 \%$ of the violence that occur in Ghanaian movies (See Chart 1 above)

\section{Physical Violence}

Physical violence in the movies was the high form of violence perpetrated against women. Fifty percent of suffered one of abuse physically or the other. Incidentally, perpetrators of this form of violence were known by the victim. Zeniel, a character in death after birth, was physically manhandled by men he came into contact with in the movies and even in some instances, her own foster mother physically abused her for flouting rules laid for her to follow. Women who suffer physical violence is a common place in Africa and according okunna (2002) wife beating in Nigeria communities is not rare. Physical abuses often cause injuries and sometimes death in the life of the victim. In the movie, Death after Birth, Zeniel, was constantly beaten by her foster parents, she reeled in pain and evidence of injuries was manifested in the movies.

Ashimolowo \& Otufale (2012) attest to the prevalence of physical violence among women within the African setting. The study mentions that there are immediate and long term effects 
of physical violence against women. When women are physically abused, they get injured and some get maimed permanently. As in the movie Death after Birth, Ashimolowo \& Otufale (ibid) admits that consequences of physical abuses are treated as one of those unfortunate situation that happen to all humans and there no conscious effort either by the victim or members of society to report the matter to the police for possible charge.

\section{Sexual Violence}

The movie, somewhere is Africa, tells the story of a chaotic situation in a country where the regime leader arbitrary brutalises the citizenry with some getting raped in the process. The movie reflects the assertion by National Center for Injury Prevention and Control (2013) that one of the breeding ground for the perpetration of sexual violence against women society is a war situation or a lawless regime. Rape, defilement and other sexual assaults were prevalent as though one has the right to perpetrate such act of criminality. According to Esere et al (2009) sexual violence against women such as rape often occur between perpetrators known by the victim. This picture painted by the study sees a manifestation in the movie death after birth, where the principal character Zeneil gets raped by two of her foster fathers she lived with. The contuse experiences of violence meted out to her made her developed a callous attitude towards violence and eventually she started perpetrating it as well in a far deadly manner.

\section{Psychological Violence}

Psychological violence is usually the aftershock experienced by the victim of physical or sexual violence. The humiliation and name calling cause instability and trauma in the life of the victim. In all three movies, women who in one way or the experienced violence, showed signs of humiliation and despair. Though in the minority, about $27 \%$ of women suffered psychological violence one or the other in their lives.

\section{Power and Violence against Women}

The findings from the study amply demonstrated that violence does in fact occur in Ghanaian movies. Most predominant of these forms are physical, sexual and psychological (see table 1 above). These findings confirm the United Nations (1993) assertion that violence against women manifest as physical, sexual or psychological abuses. The presence of physical, sexual and psychological violence in the movies is again consistent with the work by Ardayfio-Schandorf (2005) when she investigated the nature of violence in some rural communities in Ghana. Ardayfio-Schandorf explained that women in typical Ghanaian communities suffered from physical, sexual and psychological abuses.

The relationship, however, between what the media often portray as violence against women and what occur in real life as posited by Ardayfio-Schandorf (2005) gives credence to the position held by Pauwels (2008) that the visual media is a mirror to society which helps us to understand our social world. The reality of sexual violence in our communities, for instance, finds a place in media text such as in the movie Death after Birth and these portrayals are invariably consistent with happenings in real life as showed in the work of ArdayfioSchandorf.

Often, reasons for perpetrating violence against a victim in Ghanaian movies are always at the discretion of the perpetrators. Indeed it cannot be predicted what may trigger a violent 
action against a woman in all the movies that portrayed violence against women. In the movie Ties That Bind, a victim was violently manhandled because she incurred the displeasure of the perpetrator and for daring to resist an order from the military ruler in Somewhere in Africa, the victims were physically molested and some shot to death. Unable to predict what may trigger off violence from a perpetrator tends to create a vacuum of uncertainty and ostensibly position the woman as a potential victim of violence.

Underlying ones desire to perpetuate violence at will is the issue of unequal distribution of power. The patriarchal culture in most African leaves so much power and authority in the hands of men to the point that they act at will and an attempt to challenge their authority especially in a relationship is met with violent abuses. Cruz \& Klinger (2011) acknowledges that too much power in the hands of men creates a structural problem where men almost always have the edge to commit acts of violence against women

\section{Poverty and Violence against Women}

In portraying the forms of violence that women suffer in movies, it amply emerged that one of the contributing factors to the perpetration of violence against women is poverty. Total dependence on men and husbands in general created a situation of control of one's right and freedom. In Ties That Bind, the horrifying experiences of Adobea from the beginning of the plot till its end can simply be attributed to over reliance on the husband for survival. The agony of the character, Adobea, in the movie amplifies the point made by Bashiru (2012) to the effect that poverty has become a conduit for perpetrating violence against women in rural communities in Ghana.

Unable to fend for herself, the woman is physically molest by relatives, friends and strangers, sexually abused by the husband and perpetually lives in a state of psychological trauma. Unfortunately, the victim would have to stay with this challenge throughout her life because the society shows no interest in helping her out of this quagmire. Cantalupo (2006) underscores the point that women in Ghana who suffer abuses in relationships have nowhere to turn to for help within the community because the society itself supports and condones acts of violence perpetrated against the woman. The character, Adobea, became a victim in the movie of this circumstance that prevails within the Ghanaian setting.

\section{Violence and Levels of Manifestation}

According to the United Nations Declaration of Eliminating all forms of Violence against Women (UN, 1993), violence against women occur at three levels; home, community and the state. Portrayal of violence against women in Ghanaian movies tends to be more domestic than that which happen at the community level or that which is supported by the state. In fact the study findings show in Table 6 above that $67 \%$ of violence against women in movies occurred between relatives as against $33 \%$ that occurred between a victim and a stranger.

This finding is consistent with a number of reports across the globe. A National Domestic Violence Report (2010) in the United States of America states that about $85 \%$ of women have been abused by their boyfriends, former boyfriends or husbands before. A study by Innocenti Digest (2000) points to the fact that domestic violence is the most common of all the abuses across the globe. In Japan 59\% of women reported being abused by their partner, Up to $45 \%$ of married men acknowledged physically abusing their wives in India and 35\% of women in Egypt reported being beaten by their husband at some point in their marriage. The global 
picture shows that domestic violence is the highest and the most perpetuated violence against women. This fact is consistent with the kind of violence Ghanaian movies portray against women.

Evidence of violence initiated and supported at the community level is seen in Ties That Bind. A father of two was diagnosed of HIV/AIDS after prolonged sickness. Living in a traditional community where the belief in the gods is supreme, he decided to consult a deity. The advice was for him to sleep with a virgin girl after which he will receive cure for his ailment. The options available to him were limited so he pounced on her own innocent daughter and raped her. After the act, the young lady became unconscious. The larger community got wind of the act and decided to hand him an instant justice by burning him to death. His wife decided to come to his rescue by attempting to save her husband from lynching.

Unfortunately, the woman was subjected to incessant pelting of stones but she will not budge. So severe was the attack on her that the mob was just prepared to lynch her together with the husband. A timely intervention by the police saved her. In an attempt to correct an obvious wrong the community somewhat put the cart before the horse. It was more convenient for the mob to mete out instant justice than lodge an official complaint with the right authorities mandated to handle such offences. The self imposed right of power by society (mob) to commit violence makes victims of women in society. The collective resolution by the mob to lynch the woman in addition positioned the woman as a helpless victim confronted by multitudes. It was a straight struggle between one victim and a bigger community.

The movie, Somewhere in Africa portrays a picture where atrocities meted out to women is initiated and executed by the state. Gabiza, the military ruler in Somewhere in Africa was a tyrant. No one challenges his orders and the least provocation will result in ones death. The regime murdered innocent women; some were severely brutalized while others suffered sexual abuses. Women who became victims of state supported violence as portrayed in the movies were confronted with a hopeless situation especially when the organs of state such as the security forces that are supposed to protect their interest turn out to be the conduit for the perpetration of crime. According to Ward and Marsh (2006), sexual violence is a common occurrence in a war situation where social structure has broken down. Their report points out that women and girls suffered sexual brutalities from military officers who took advantage of a chaotic situation and virtually turned girls into sex slaves. The movie's account in Somewhere in Africa, effectively show us the visuals that reflect the reality of what women go through in the hands of the state especially during a chaotic situation.

\section{In What Forms Do These Acts Of Violence Against Women Manifest In The Movies?}

The results also show that portrayal of violence against women in Ghanaian movies manifested in various ways. Physical violence was portrayed in forms of beating, stabbing, kicking and shooting. In all, 13 incidences of physical violence were portrayed in all three movies. (See Table 2 below). Beating was recorded 6 times in all the three movies; representing a percentage score of $46 \%$ for physical violence perpetrated against women in Ghanaian movies, Pushing, 4, representing 31\%, Stabbing, 1, representing 8\% and Shooting, 2 , representing $15 \%$. Incidences in the movies such as slapping of Zeneil (a principal character) in Death After Birth, physical molestation of young girls and women in 
Somewhere In Africa and the pelting of stones at an innocent woman in Ties That Bind demonstrates the presence of physical violence in Ghanaian movies.

Table 2. Scope and frequency of physical violence

\begin{tabular}{lcccc}
\hline \multicolumn{1}{c}{ Movies } & $\begin{array}{c}\text { Beating } \\
(\boldsymbol{\%})\end{array}$ & $\begin{array}{c}\text { Pushing } \\
(\boldsymbol{\%})\end{array}$ & $\begin{array}{c}\text { Stabbing } \\
(\boldsymbol{\%})\end{array}$ & $\begin{array}{c}\text { Shooting } \\
(\boldsymbol{\%})\end{array}$ \\
\hline Ties That Bind & $1(50 \%)$ & $1(50 \%)$ & $0(0 \%)$ & $0(0 \%)$ \\
Somewhere In Africa & $2(40 \%)$ & $1(20 \%)$ & $0(0 \%)$ & $2(40 \%)$ \\
Death after Birth & $3(50 \%)$ & $2(33 \%)$ & $1(17 \%)$ & $0(0 \%)$ \\
Total & $\mathbf{6 ( 4 6 \% )}$ & $\mathbf{4 ( 3 1 \% )}$ & $\mathbf{1 ( 8 \% )}$ & $\mathbf{2 ( 1 5 \% )}$ \\
\hline
\end{tabular}

Abuses against women in Ghanaian movies also manifested in a form of sexual violence. The scope of the violence was in two folds; rape and defilement. All the movies used for the study portrayed incidences of sexual violence against women. In the movie Somewhere in Africa, young ladies were raped after they had been abducted by the military regime; Zeneil, a principal character in Death after Birth was subjected to several bouts of sexual abuse by her foster parent at a very tender age and an incestuous act between a father and daughter is portrayed in Ties That Bind. The table below shows the scope and the frequency of sexual violence in the movies.

Table 3. Scope and frequency of sexual violence

\begin{tabular}{lcc}
\hline Movie & $\begin{array}{c}\text { Rape } \\
(\boldsymbol{\%})\end{array}$ & $\begin{array}{c}\text { Defilement } \\
(\boldsymbol{\%})\end{array}$ \\
\hline Somewhere In Africa & $0(0 \%)$ & $1(100 \%)$ \\
Ties That Bind & $2(100 \%)$ & $0(0 \%)$ \\
Death after Birth & $1(33 \%)$ & $2(67 \%)$ \\
Total & $\mathbf{3 ( 5 0 \% )}$ & $\mathbf{3}(\mathbf{5 0 \%})$ \\
\hline
\end{tabular}

Beyond physical and sexual violence, the movies also portrayed another range of abuses which were neither sexual nor physical. The nature of these abuses sought to chip away the self image of the victim. It manifested through name calling, shaming, intimidation and total isolation. In the movie, Ties That Bind for instance, Adobea, a character in the movie, was vehemently and continuously accused by her in-laws that she was a witch. The in-laws claimed the only reason why all seven of her children died soon after delivery was because she feasted on them. Zeneil in Death after Birth, laments the psychological trauma she was 
going through and in her own words she reports; 'life has been painful and cruel to me'; I hate myself and everyone around me'; I became bitter as the days go by'. The actions and commentary of victims in the movie amply demonstrated the trauma they were going through. The table below shows the scope of psychological abuses suffered by the victims in the movies and the frequency with which they occurred.

Table 4. Scope and frequency of psychological violence

\begin{tabular}{lcccc}
\hline Movie & $\begin{array}{c}\text { Intimidation } \\
(\%)\end{array}$ & $\begin{array}{c}\text { Shaming } \\
(\%)\end{array}$ & $\begin{array}{c}\text { Isolation } \\
(\%)\end{array}$ & $\begin{array}{c}\text { Name Calling } \\
(\%)\end{array}$ \\
\hline Ties That Bind & 0 & 0 & 0 & 1 \\
Somewhere In Africa & 2 & 0 & 0 & 0 \\
Death after Birth & 2 & 1 & 1 & 0 \\
Total & $\mathbf{4 ( 5 7 \% )}$ & $\mathbf{1 ( 1 4 \% )}$ & $\mathbf{1 ( 1 4 \% )}$ & $\mathbf{1 ( 1 5 \% )}$ \\
\hline
\end{tabular}

Generally, violent acts committed against women in the movies were done by men though female characters were occasionally involved. Whether it was physical, sexual or psychological violence, the movies portrayed men as the key perpetrators of the crime. The table below demonstrates the characters most actively involved in violence against women as portrayed in Ghanaian movies.

\section{Portrayed Forms of Physical Violence in Movies}

\section{Beating}

Physical violence against women in the movies manifested in a form of beating and represented $46 \%$ of all the forms of physical violence perpetrated against women in the movies. A study by Ardayfio-Schandorf (2005) points out that one of the ways that women are physically abused is through beating either with a hand or a weapon. Though there were incidents of beatings in all the movies, it was not restricted on only wife battering but it was across board; including students, ordinary women on the streets and mere acquaintances.

\section{Pushing}

Pushing of a victim in the movies again was used as a way of perpetuating physical violence against women. At least $31 \%$ of the women who were physically abused were pushed. The effect however was injury to the victim. The presence of pushing as a conduit for physical violence confirms the WHO (2002) report that one of the ways women are physically victimised is true pushing of the victim. The reason for the violent act as in the case of Somewhere in Africa has to do with ones dissatisfaction and a feeling of disobedience by a woman towards his authority. 


\section{Stabbing}

Physical violence again manifested in a form of stabbing in the movies under study. As posited in Innocenti Digest (2000), some form of violence perpetrated against women is life threatening. Women suffer multiples of injuries as a result and some die in the process.

\section{Shooting}

As in the case of stabbing, women who were shot in the movies as in the case of Somewhere in Africa lost their lives. Often the reason for taking a victims life is merely a show of power. Indeed, the movies showed that $15 \%$ of the incidents of physical violence manifested in a form of shooting.

\section{Portrayed Forms of Sexual Violence in Movies}

\section{Rape and Defilement}

Rape is one of the forms of sexual violence perpetrated against women in the movies selected for the study. At least $50 \%$ of victims suffered from rape related incidents in the movies. Bashiru (2012) in his study of the nature of sexual violence common to the people in the northern part of Ghana, it emerged that rape as well as defilement were the most perpetrated forms of sexual violence that women suffer from men. When rape occurs in marriages, the act incident is not considered to be an offense however, when it is not even in a marriage situation, the victims refuse to report the matter to any appropriate authorities for redress. The community, in which such offences occur, look on unconcerned but best they try to resolve the matter amicably. In death after birth, victims of sexual violence such as rape and defilement suffered their fate alone without any form of assistance from the society. The perpetrators used violence as a means of punishing their victims.

\section{Portrayed Forms of Psychological Violence in Movies}

The manifested forms of psychological violence in the movies included, Intimidation,

Shaming, Isolation, Name Calling. These forms of violence occurred as a consequence to sexual and physical violence that have been perpetrated against the victims. These forms of violence sought to chip away the joy and the self image of the victims. Perpetrator looked on unconcerned as victims battle for inner survival. 


\section{Perpetrators of Violence against Women}

Table 5. Gender distribution of perpetrators of violence against women in Ghanaian movies.

\begin{tabular}{llc}
\hline Movie & $\begin{array}{c}\text { Male } \\
(\boldsymbol{\%})\end{array}$ & $\begin{array}{c}\text { Female } \\
(\boldsymbol{\%})\end{array}$ \\
\hline Ties That Bind & $3(50 \%)$ & $3(50 \%)$ \\
Somewhere In Africa & $7(64 \%)$ & $4(36 \%)$ \\
Death after Birth & $7(64 \%)$ & $4(36 \%)$ \\
Total & $\mathbf{1 7}(\mathbf{6 1 \% )}$ & $\mathbf{1 1 ( 3 9 \% )}$ \\
\hline
\end{tabular}

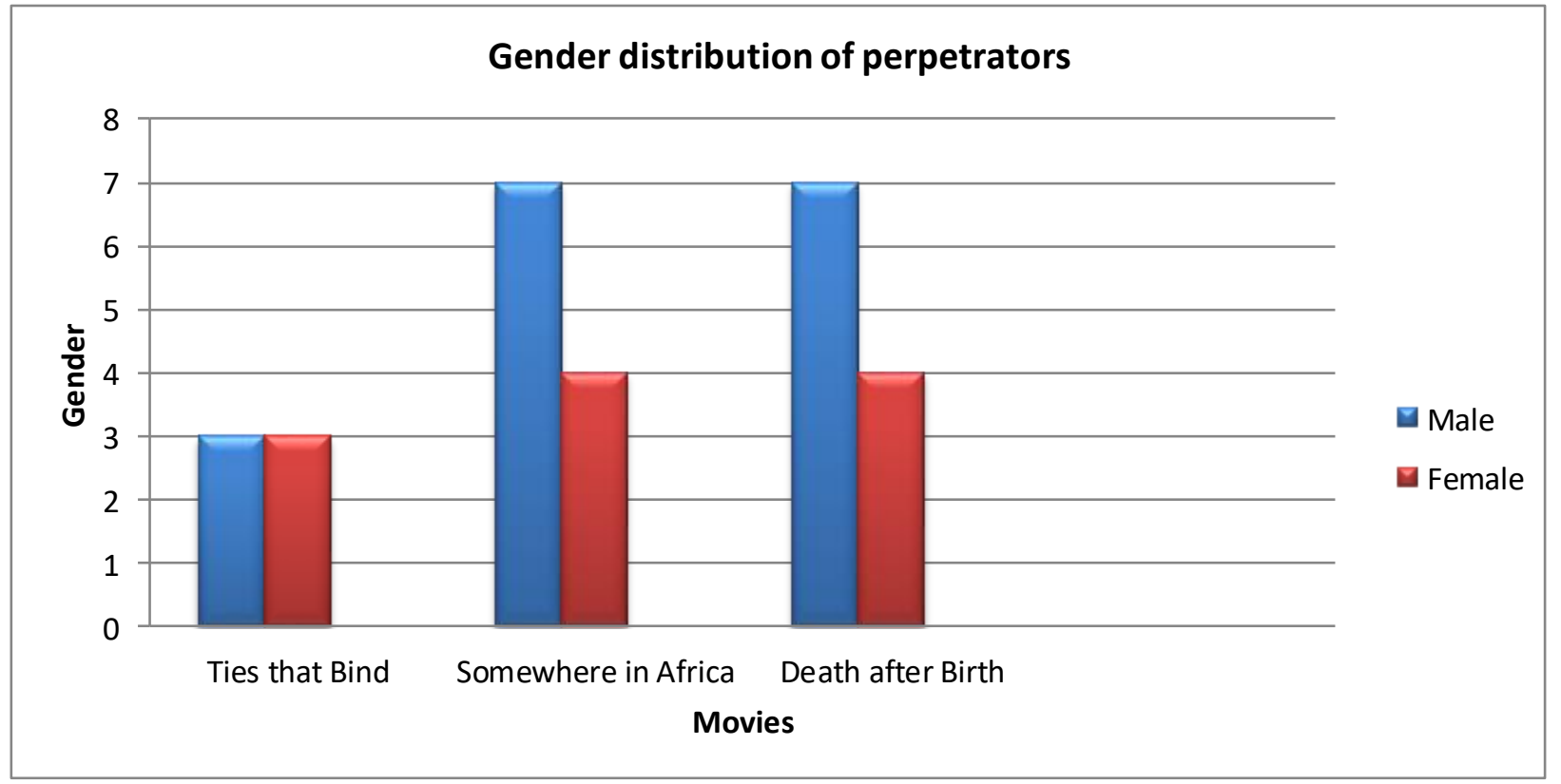

\section{Chart 2}

Chart 2 shows that in the movie Ties That Bind, the number of male perpetrators equalled the number of female perpetrators. The movie, Somewhere in Africa shows that male perpetrators were 7 representing $64 \%$ while female perpetrators were 4 in number, representing 36\%. 7 male perpetrators representing $64 \%$ and 4 female perpetrators representing $36 \%$ were recorded in the movie Death after Birth.

In the portrayal of violence against women in Ghanaian movies, the relationships between the perpetrators and the victims in the movies were unambiguous. Often, the perpetrators were known by the victim and vice versa. Relatives committed more violent crimes against women 
in Ghanaian movies than strangers did. The table below demonstrates the relationship between the victims and the perpetrators.

Table 6: Relationship between victim and perpetrator

\begin{tabular}{lcccc}
\hline Movie & $\begin{array}{c}\text { Spouse } \\
(\mathbf{0 \%})\end{array}$ & $\begin{array}{c}\text { Friend } \\
(\mathbf{0 \%})\end{array}$ & $\begin{array}{c}\text { Relative } \\
(\mathbf{0 \%})\end{array}$ & $\begin{array}{c}\text { Stranger } \\
(\mathbf{0 \%})\end{array}$ \\
\hline Ties That Bind & $0(0 \%)$ & $0(0 \%)$ & $1(100 \%)$ & $0(0 \%)$ \\
Somewhere In Africa & $0(0 \%)$ & $0(0 \%)$ & $0(0 \%)$ & $2(100 \%)$ \\
Death after Birth & $0(0 \%)$ & $0(0 \%)$ & $3(100 \%)$ & $0(0 \%)$ \\
Total & $\mathbf{0}(\mathbf{0 \%})$ & $\mathbf{0}(\mathbf{0 \%})$ & $\mathbf{4}(\mathbf{6 7 \%})$ & $\mathbf{2 ( 3 3 \% )}$ \\
\hline
\end{tabular}

The results posted in table 6 show that $67 \%$ of violent acts perpetrated against women were committed by relatives while $33 \%$ of such acts were committed by strangers. The movies did not portray friends and spouses committing any form of violence against women.

\section{Gendered patterns in the perpetration of violence against women}

According to Tracy (2007), most feminists hold the strong view that the ultimate and the necessary cause of all forms of abuse against women is patriarchy. The discourse explains that patriarchy is the rule and dominance by men where they are the subjects and the woman and children are the objects. A report by the United Nations (2007) suggests that half of all women who die from homicide are killed by their current or former husbands or partners. The report demonstrates that in Australia, Canada, and Israel, 40 to 70 per cent of female murder victims were killed by their partners, while in South Africa, a woman is killed every six hours by an intimate partner and in the United States, one-third of women murdered each year are killed by intimate partners.

The investigation into the Portrayal of Violence against Women in Ghanaian Movies confirms the assertion that men are actively involved in perpetrating violence against women. The results in Table 5 above in this study amply demonstrate this position. $61 \%$ of all forms of violence perpetrated against women in Ghanaian movies were committed by men while $39 \%$ were committed by women against other women. The findings, however, made by the study show that women are equally guilty of perpetrating violence against other women in Ghanaian movies.

Often, feminist film critics have solely focused on men as the active participants in committing violence against women. While this position is not in doubt, the blurred reality is that women are equally liable in perpetrating violent crimes against other women. 


\section{Ghanaian Movies and the Reinforcement of Violence against Women}

\section{Movie portrayal of women}

The study on Portrayal of Violence against Women in Ghanaian Movies also seeks to increase our understanding of how women are represented in Ghanaian movies. It is worth mentioning however that, how women are portrayed in movies also touches on the image they are associated with.

The analysis of the movies in this study points to incidences in Ghanaian movies where women are portrayed as helpless victims who are beaten at will, pushed violently, stabbed and even shot to death. This image of women as helpless victims is actively reinforced in the movies as everyone including the bigger society looks on unconcerned while the victims are left to bear their pain alone. Indeed, their plight is treated with contempt; they suffer alone and eventually fall alone.

Ironically, these acts of violence against women in the movies either go unnoticed by the perpetrator, treated with contempt by friends, shelved by family members or go unreported by the victim. In the movie Ties That Bind, a victim of abuse, Adobea, was made to go through a humiliating experience of undressing in front of a traditional herbalist and her inlaw to pave way for rituals to be performed to protect mother and unborn child from death. Her protest fell on deaf ears and she stood in the midst of a gathering helpless while her body is controlled by others. Ironically, even when the victim finds a voice to speak and protest the treatment of her body, stronger forces within the social structure such as parents and in-laws cow her down into submission.

Indeed, the portrayal of abused women as helpless victims in Ghanaian movies is deeply rooted in the concept of stereotyping. The stereotypical imagery of abused women in Ghanaian movies as helpless victims tend to provoke an extreme anger in victims who somewhat decide to revenge to restore their image and assert their human rights status. A victim, Zeneil, in Death after Birth, challenged the status quo where women are treated with contempt and are arbitrary abused in a world controlled by patriarchal dictates. She fought back to restore her image and pride.

Unfortunately, her struggle ended tragically. The reinforcement of abused women in Ghanaian movies as helpless victims confirms the study by Onyejekwe (2004) to the effect that the movies continue to portray women as objects of victimisation; positioning them as helpless victims in a world where patriarchal codes tend to govern our way of life. A brazen attempt by a woman to defy the social structure where men rule may result in tragedy as evidenced in Death after Birth.

\section{Movie and reflection of violence}

Ghanaian movies, as stated earlier, portray acts of violence against women in different forms. As a microcosm of the mass media, movies influence our way of thinking in different forms and at different levels (Bastian et al 2013). However, central to the movies' portrayal of violence against women is whether such portrayals merely reflect the reality as it exists in our communities or it is a creation by film makers to distort the reality. The portrayal of violence against women in Ghanaian movies as a reflection of social reality is not in doubt. 
The movies, 'Ties That Bind,' 'Somewhere In Africa' and 'Death after Birth', portrayed violent scenes against women which were consistent with the findings made by ArdayfioSchandorf (2005) and Ward and Marsh (2006) to the effect that violence against women happen in our society. Ardayfio-Schandorf explained that about $6 \%$ of females said they have been defiled before. Ironically, $78 \%$ of the perpetrators of this crime happen to be their close relations. The study also asserted that wife beating is a common phenomenon in their community and about $23 \%$ of women said they have been beaten by their husbands and boyfriends before. The link between what happen in real life and what get portrayed in Ghanaian movies is not at variance.

The movies showed that physical violence is a common feature in society against women and such violent acts were perpetrated by close relations of the victim. The incidences of psychological trauma, physical abuses such as beating and stabbing and sexual abuses such as rape and defilement found their representation in media text not merely as a construction of reality but a reflection of the reality. These portrayals that clearly reflected the happenings in our real world context also go a long way to reinforce acts of violence against women (Onyejekwe, 2004).

The discourse argues that the portrayal of violence against women in the visual media has a sense of reality and the continuous exposure of these realities reinforce acts of violence against women. Again, Onyejekwe argues that though media texts may have gaps in portraying the woman as a victim of violence, the ultimate issue here is that what is represented in movies is consistent with happenings in society. According to Jordaan et al (2011) violence against women in movies is authenticated through regular exposures and then adopted by the public as the norm.

Though violence against women is a reality, country by country has laws that frown on such practices. According to the United Nations (2010), member countries are to

- Ensure that laws against family violence and abuse, rape, sexual assault and other gender-based violence give adequate protection to all women, and respect their integrity and dignity; and

- Take all legal and other measures that are necessary to provide effective protection of women against gender-based violence, including effective legal measures, including penal sanctions, civil remedies and compensatory provisions to protect women against all kinds of violence

According to Archampong (2010), the Domestic Violence Act, 2007(Act 732) provides a legal framework that deals with the issue of domestic violence in Ghana. The discourse argues that these laws frown on violence against women and invariably provide protection for the woman victim. In this sense, the active portrayal of abused women as helpless victims in the movies may be erroneous especially when there are remedial measures to protect their rights and image as well. To the extent that the movies solely portray violence against women without offering the viewers the remedy for such human rights abuses leaves a lot of doubt on the claim that the media only reflect reality.

However, it is instructive to observe that in all the movies that portray violence against women, there was no point in time in the movies where the victim sought legal redress to protect her rights. In 'Death after Birth', the victim fought her own battles till her tragic end. 
There was no scene in the movie where support agencies in the society ever came to the victim's aid in 'Death after Birth' even though her teacher was well aware of the trauma the young victim of sexual and psychological abuse was going through.

Indeed the reluctance of the victims to report cases as portrayed in the movies makes the laws that seeks to protect their right somehow redundant. According Kaur \& Garg (2008), the reasons why women are unwilling to report incidences of violence perpetrated against them are due to their dependence on their partners for survival. Their inability to sustain themselves economically forces them to stay in abusive relationships. Again the discourse explains that deep-rooted cultural and traditional values discourage the woman victim from reporting the husband. Such an attempt is viewed as disgracing your husband and washing you dirty linen in the public domain. The perception that she may be viewed as a battered woman in society largely compels her not to report the case at all.

According to Srivastva and Agarwal (2004), as the visual media continue portray acts of violence against women it reinforces the phenomenon and ostensibly, the mind of the viewer gets desensitised. Eventually, violence against women becomes a normal phenomenon in the mind of the viewer. The normalisation of violence, however, is amply reinforced in movies on three levels; personal, family and state. On the personal level, victims take no action on criminal acts perpetrated against them except to subject themselves to prolonged emotional trauma. Indeed victims of violence occasionally resort to friends and close relative for help. Ironically the help comes in a form of consolation but no steps are taken to seek redress at the appropriate quarters to restore the pride of the victim. As a victim of abuse, Adobea, a character in 'Ties That Bind' resigned herself to her fate and somehow decided to suffer alone. The only help she got was a friendly encouragement.

The family is another front that consciously or unconsciously, endorses acts of violence against women folk in society. More often than not, Ghanaian movies portray the family as agents of society whose contributions are indispensable. However, the family is portrayed as highly reluctant in chastising perpetrators of violence against women especially in the homes. Their cold attitude in looking on for these acts to still dominate within the cultural setting is not only worrying but smacks of betrayal of trust and confidence that society has in the family system in helping to curb this global menace of violence against women. It is not surprising to note that the findings in this study revealed that $67 \%$ of all the abuses that women suffered from were in a form of domestic violence. Even when parents are aware of violence they tend to protect the perpetrator instead as evidenced in 'Ties That Bind.'

Particularly worrying is the lack of effort on the part of state institutions to help eradicate this menace from our society. Admittedly, the extent to which the state can act depends on the amount of information available to them. Interestingly, the movies portray a situation where victims are unwilling to report their condition to any legally mandated institution to deal with such issues. The failure on the part of both victims and support groups to report these cases to a legally mandated body demonstrates the lackadaisical attitude in dealing with such abuses. The sheer lack of interest in confronting violence against women as portrayed in Ghanaian movies reinforces the mental picture in the minds of the viewer that violence against women is a normal wrong which eventually goes unpunished. 


\section{Violence against Women and the Millennium Development Goals}

In an effort to eliminate power differentials and achieve gender equality between males and females, the United Nations through its member countries, pledged to "combat all forms of violence against women' as a step to the realisation of the Millennium Development Goals by the year 2015 (Millennium Declaration, 2000). The role of the media, however, in this global fight is indispensable.

The movies in Ghana indeed portray violence against women but the challenge again is the failure of the media to aggressively fight this global menace. The researcher observed that in all the movies assembled for the study, the media text failed to include educational guidelines for victims as to how they should seek redress when they fall prey to such unfortunate occurrences. The media may be mirroring society but the gaps in the portrayal of reality especially with respect to violence against women tends to threaten the realisation of the Millennium Development Goal of eradicating all forms of violence against women.

\section{CONCLUSION}

Our understanding of how Ghanaian movies portrayed women was addressed in this study. On whether the movies portrayed violence against women, the answer is yes. Ghanaian movies portrayed physical, sexual and psychological violence against women. Though these portrayals may appear negative as argued by feminist film theorist, the study observed that these portrayals are indeed a reflection of the reality that women are confronted with in a real life situation.

The stories told in these movies are not merely creations of one's imagination rather a representation of a real life scenario. The study by Ardayfio-Schandorf (2005), Cantalupo (2006) and Bashiru (2012) are consistent with what Ghanaian movies portray and suggest that what gets portrayed is not a distortion rather a representation of reality. Onyejekwe (2004) on his part argues that as real as these portrayals may look, such exposures reinforce violence against women at the same time.

\section{REFERENCES}

Aguilar, L. (2006). Ouch! That stereotype hurts: Communicating respectfully in a diverse world. The Walk The Talk Company.

Alokan, F. B. (2013). Domestic Violence Against Women: A Family Menace. European Scientific Journal, 9(19).

Amenu, D., \& Hiko, D. (2014) Sexual Assault: Pattern and Related Complications Among Cases Managed In Jimma University Specialized Hospital. Ethiop Journal Health Science, 24 (1).

Anderson, C. A., Berkowitz, L., Donnerstein, E., Huesmann, L. R., Johnson, J. D., Linz, D., \& Wartella, E. (2003). The influence of media violence on youth. Psychological science in the public interest, 4(3), 81-110.

Archampong, E. A. (2010). Marital rape-A women's equality issue in Ghana. Faculty of Law, KNUST, Kumasi. 
Ardayfio-Schandorf, E. (2005). Violence against women: The Ghanaian case. In An Expert Group Meeting organized by the UN Division for the Advancement of Women on the theme" Violence against women: a statistical overview, challenges and gaps in data collection and methodology and approaches for overcoming them.

Ashimolowo, O. R., \& Otufale, (2012). G. A. Assessment of Domestic Violence among Women in Ogun State, Nigeria. Greener journal of social sciences, 3(3).pp 102-114.

Atakav, E. (2010, August 4). Representations and/or Interpretations: Women in Middle Eastern Film. Near East Quarterly.

Azeez, A. L. (2010). Audience perception of portrayals of women in Nigerian home video films. Journal of Media and Communication Studies, 2(9), 200-207.

Baker, L. L., \& Cunningham, A. J. (2005). Learning to listen, learning to help: understanding woman abuse and its effects on children. Ontario, Canada: Centre for Children \& Families in the Justice System.

Bashiru, A. M. (2012). Sexual Violence Against Women And Their Human Rights In The Wa Municipality In The Upper West Region Of Ghana.

Berberick, S. N. (2010). The Objectification of Women in Mass Media: Female Self-Image in Misogynist Culture. The New York Sociologist, 5.

Blum, L. (2004). Stereotypes and stereotyping: A moral analysis. Philosophical papers, $33(3), 251-289$.

Bushman, B. J., \& Anderson, C. A. (2001). Media violence and the American public: Scientific facts versus media misinformation. American Psychologist, 56(6-7), 477 489

Cantalupo, N., Martin, L. V., Pak, K., \& Shin, S. (2006). Domestic violence in Ghana: the open secret. Geo. J. Gender \& L., 7, 531.

Castillo, J. J. (2009). Research population. Retrieved July, 29, 2011, from http://www.experiment-resources.com/research-population.html

Chaudhuri, S. (2006). Feminist Film Theorists: Laura Mulvey, Kaja Silverman, Teresa de Lauretis, Barbara Creed. Routledge.

Coker-Appiah, D., \& Foster, J. (2002). Advocacy for better Implementation of Women's Rights in Ghana. In Convention on the Elimination of all Forms of Discrimination Against Women (CEDAW) advocacy paper. Accra, Ghana.

Croteau, D., \& Hoynes, W. (2003). Media Society: Industries, images, and audiences (3rd ed.). Sage Publications, Inc.

Chong, J. (2010). Men as Cultural Ideals: How Culture Shapes Gender Stereotypes. Harvard Business School. Retrieved June, 12, 2011. http://www.hbs.edu/faculty/Pages/download.aspx?name=10-097.pdf"

Cruz, A., \& Klinger, S. (2011). Gender-based violence in the world of work: Overview and selected annotated bibliography. ILO.

Das, R. (2012). Representation Of Violence Against Women In Indian Print Media: A Comparative Analysis. (Indian, Ed.) Global Media Journal, 3(1).

De Vaus, D. (2001). Research Design in Social Research. London: Sage Publications, Inc.

Donohoe, M. T. (2004). Partner Abuse and Sexual Assault. Hospital Physician, 25.

Elo, S., \& Kyngäs, H. (2008). The qualitative content analysis process. Journal of advanced nursing, 62(1), 107-115.

Esere, M. O., Idowu, A. I., Durosaro, I. A., \& Omotosho, J. A. (2009). Causes and consequences of intimate partner rape and violence: Experiences of victims in Lagos, Nigeria. Journal of AIDS and HIV Research Vol, 1(1), 001-007. 
Ferguson, C. J. (2009). Media Violence Effects and Violent Crime. Violent Crime: Clinical and Social Implications, 37.

Fraser, K., \& Clearinghouse, F. V. (2003). Domestic violence and women's physical health. Australian Domestic \& Family Violence Clearinghouse.

Funk, J. B., Baldacci, H. B., Pasold, T., \& Baumgardner, J. (2004). Violence exposure in real-life, video games, television, movies, and the internet: is there desensitization? Journal of Adolescence, 27(1), 23-39.

Hancock, B. (2002). Trent Focus for Research and Development in Primary Health Care: An Introduction to Qualitative Research. Trent Focus.

Harvard Humanitarian Initiative (2009). Characterizing Sexual Violence in the Democratic Republic of the Congo.

Heins, M., Cantor, J., Jenkins, H., Niehoff, D., Savage, J., Corn-Revere, R., Smolla, R., \& O'Neil, R. (2001). Violence and the media: An exploration of cause, effect and the First Amendment. First Amendment Center. Retrieved April, 19, 2013, from http://www.freedomforum.org/publications/first/violenceandmedia/violenceandthemedi a.pdf

Higgs, J., Horsfall, D., \& Grace, S. (2009). Writing Qualitative Research on Practice. Sense Publishers.

Holtzhausen, T., Jordaan, Y., \& North, E. J. (2011). The portrayal of women in South African television commercials. Southern African Business Review, 15(3), 167-183.

Ibroscheva, E \& Ramaprasad, J. (2008). Do media matter? A social construction model of stereotypes of foreigners. Journal of Intercultural Communication, 16,

Jensen, R., \& Oster, E. (2009). The power of TV: Cable television and women's status in India. The Quarterly Journal of Economics, 124(3), 1057-1094.

Jewkes, R. (2002). Intimate partner violence: causes and prevention. The Lancet, 359(9315), $1423-1429$.

Kafiris, K. (2005). The Gender and Media Handbook: Promoting Equality, Diversity and Empowerment. Mediterranean Institute of Gender Studies.

Kaiser Family Foundation (2003). Key Facts: TV Violence. Retrieved July, 25, 2011, from http://kff.org/hivaids/tv-violence

Kambarami, M. (2006). Femininity, sexuality and culture: Patriarchy and female subordination in Zimbabwe. South Africa: ARSRC.

Kameri Mbote, P. (1996). Violence Against Women in Kenya. An Analysis of Law, Policy and Institutions Legal Education Materials

Kaufman, M. (1999). The seven p's of men's violence. web autor: http://www. michaelkaufman. com.

Kaul, S., \& Sahni, S. (2010). Portrayal of women in television (TV) serials. Studies on Home and Community Science, 4(1), 15-20.

Kaur, R., \& Garg, S. (2008). Addressing domestic violence against women: an unfinished agenda. Indian Journal of Community Medicine: Official Publication of Indian Association of Preventive \& Social Medicine, 33(2), 73.

Kellner, D. (2002). Critical perspectives on visual imagery in media and cyberculture. Journal of Visual Literacy, 22(1), 81-90.

Khan, M. (2000). Domestic Violence against Women and Girls. Innocenti Digest 6.

Khasakhala-Mwenesi, B., Buluma, R. C., Kong'ani, R. U., \& Nyarunda, V. M. (2004). Gender violence. Kenya Demographic and Health Survey 2003.

Krug, E. G., Mercy, J. A., Dahlberg, L. L., \& Zwi, A. B. (2002). World Report on Violence and Health. Geneva, World Health Organisation. 
Langton, L., Krebs, C., Berzofsky, M., \& Smiley-McDonald, H. (2013). Female victims of sexual violence, 1994-2010. US Department of Justice, Office of Justice Programs, Bureau of Justice Statistics

Larasi, M. (2012). Media as a Site to Prevent Violence against Girls and Women. Paper Presented At Expert Group Meeting for the Prevention of Violence against Women and Girls. Bangkok, Thailand.

Louis, W., Burke, S., Pham, H., \& Gridley, H. (2013). Media Representations and Responsibilities: Psychological Perspectives.

Ma, R. S. B. (2000). The role of qualitative research in broadening the 'evidence base' for clinical practice. Journal of evaluation in clinical practice, 6(2), 155-163.

Mabasa, T. B. (2009). Understanding and preventing rape: perceptions of police officers in inner city Johannesburg (Doctoral dissertation).

Made, P. (2008). Women in the News: Strengthening the Voice and Visibility of Women in the African Media's Coverage of Elections, Politics and Governance. A Handbook for Women Politicians and the Media. Inter Press Service, Africa.

Marshall, L. (2004). Media Culpability in the Continuum of Violence against Women. Retrieved July, 27, 2011, from http://www.countercurrents.org/gendermarshall300904.htm.

Mayoux, L. (2000). Retrieved January 19, 2012, from http://www.enterpriseimpact.org.uk/word-files/QualMethods.doc

McCabe, J. (2004). Feminist Film Studies: Writing the Woman Into Cinema. Wallflower Press.

McGarty, C., Yzerbyt, V. Y., \& Spears, R. (Eds.). (2002). Stereotypes as explanations: The formation of meaningful beliefs about social groups. Cambridge University Press.

Media Education Foundation (2005). Media Violence: Facts \& Statistics. Retrieved April, 13, 2011, from http://www.jacksonkatz.com/PDF/ChildrenMedia.pdf\}

Morhe, R. A. S., \& Morhe, E. S. K. (2013). The Law on Defilement in Ghana and Challenges in its Implementation at the Ejisu-Juabeng Domestic Violence and Victims Support Unit of the Ghana Police Service. Journal of Law, Policy and Globalization, 16(2), 2329.

Myhill, A., \& Allen, J. (2002). Rape and sexual assault of women: the extent and nature of. Home Office Research, Development and Statistics Directorate.

Neuman, S. (2013). The issue of sexual violence against women in contemporary India.

National Center for Injury Prevention and Control (2012). Sexual violence. Retrieved June 9, 2013. From http://www.cdc.gov/violenceprevention/pdf/sv-datasheet-a.pdf

Nnadi, I. (2012). An Insight into Violence against Women as Human Rights Violation in Nigeria: A Critique. Journal of Politics \& Law, 5(3).

Novak, T. (2005). Mass Media and the Concept of Ideology. Media and Social Theory, New School for Social Research.

Okunna, C. S. (2002, July). Gender and communication in Nigeria: is this the twenty-first century?. In paper delivered at International Association for Media and Communication Research (IAMCR) biennial conference, Barcelona, Spain.

Onyejekwe, C. J. (2004). Violence against Women: An Issue of Health and Human Rights. Nebula, 1(1), 32-7.

Parents Television Council. (2009). Women in Peril: A Look at TVS' Disturbing New Storyline Trend. Special Report. Parents Television Council.

Parvez, M. A., \& Robina, R. (2010). Mass Media and Women: A Study on Portrayal of Status and Violence. Pakistan Journal of Social Sciences, 3(1), 133-140. 
Pauwels, L. (2008). Visual literacy and visual culture: Reflections on developing more varied and explicit visual competencies. Open Communication Journal, 2, 79-85.

Petersen, I., Bhana, A., \& McKay, M. (2005). Sexual violence and youth in South Africa: The need for community-based prevention interventions. Child abuse \& neglect, 29(11), 1233-1248.

Prentice, D. A., \& Carranza, E. (2002). What women and men should be, shouldn't be, are allowed to be, and don't have to be: The contents of prescriptive gender stereotypes. Psychology of Women Quarterly, 26(4), 269-281.

Savage, J. (2004). Does viewing violent media really cause criminal violence? A methodological review. Aggression and Violent Behavior, 10(1), 99-128.

Smelik, A. (1998). And the mirror cracked: feminist cinema and film theory, 492-496, London, Macmillan

Srivastva, S. K., \& Agarwal, S. (2004). Do the Visual Media Contribute to Violence Against Women?. Journal of Social Studies, 9, 63-65.

Stankiewicz, J. M., \& Rosselli, F. (2008). Women as sex objects and victims in print advertisements. Sex Roles, 58(7-8), 579-589.

Sukamolson, S. (2007). Fundamentals of quantitative research. Language Institute Chulalongkorn University, 1-20.

Thaler, K. (2012). Norms about intimate partner violence among urban South Africans: a quantitative and qualitative vignette analysis. CSSR Working Paper, (302).

Tracy, S. (2007). Patriarchy and Domestic Violence: Challenging Common Misconceptions. Journal of the Evangelical Theological Society. 50(3),580-583.

United Nations. (1993). "Declaration on the elimination of violence against women. Resolution A/RES/48/104. New York, United Nations: United Nations General Assembly.

United Nations Economic Commission for Africa (2006). Violence against Women in Africa: A Situational Analysis. Retrieved 14 April 2013. From www1.uneca.org/awro/ArticleDetail/tabid/5146/ArticleId/.../Default.aspx

United Nations (2007). The United Nations General Assembly. Resolution A/RES/61/143, United Nations, 30 January.

United Nations. (2008). What is the United Nations doing to end violence against women and girls? Fact sheet DPI/2546A, United Nations.

United Nations Statistical Commission. (2009). Meeting of the Friends of the Chair of the United Nations Statistical Commission on Statistical Indicators on Violence against Women. Aguascalientes, Mexico.

United Nations (2010), Handbook for Legislation on Violence against Women. New York, United Nations.

Van Niekerk, W. J. (2005). Emotional experiences of incestuous fathers: a social constructionist investigation.

VanWynsberghe, R., \& Khan, S. (2008). Redefining case study. International Journal of Qualitative Methods, 6(2), 80-94.

Wales, L. M. (2002). Progression Or Oppression?: Violence Against Women In Leading Roles In Hollywood Cinema, 1990-1995:. Expanding Our Horizons. University Of Sydney, Australia.

Ward, J., \& Marsh, M. (2006, June). Sexual violence against women and girls in war and its aftermath: Realities, responses, and required resources. In Symposium on Sexual Violence in Conflict and Beyond (Vol. 21, p. 23). 
Watts, C., \& Zimmerman, C. (2002). Violence against women: global scope and magnitude. The Lancet, 359(9313), 1232-1237.

Welsh, A., \& Brantford, L. (2009). Sex and violence in the slasher horror film: A content analysis of gender differences in the depiction of violence. Journal of Criminal Justice and Popular Culture, 16(1).

World Health Organisation (2009). Violence against Women. Fact sheet $N^{\circ} 239$. Geneva, WHO.

World Health Organization. (2009). World health statistics 2009. World Health Organization.

World Health Organization. (2012). Understanding and addressing violence against women. WHO.

Yusuf, N. (2009). Incidence and Dimension of Violence against Women in the Nigerian Society: A Case Study of Ilorin Township.

Wright, M. (2005). Stereotype of women are widespread in media and society. The Quinnipiac chronicle. Retrieved august 21, $2012 . \quad$ From http//www.quchronicle.com/2005/02/stereotype-of-women-are-widespread-in-mediaand-society

Zhang, Y., \& Wildemuth, B. M. (2009). Qualitative analysis of content. Applications of social research methods to questions in information and library science, 308-319. 